\title{
Juan de Mena's arte mayor verse in Laberinto de fortuna: Identifying and describing a Spanish dolnik
}

\author{
Jesús M. Saavedra Carballido*
}

\begin{abstract}
The metre used by the Spanish writer Juan de Mena in his long allegorical work Laberinto de fortuna has been puzzling metrists for over five centuries. Usually identified as a variety of the verse called arte mayor, this metre has been analysed, among other things, as a divided line - one systematically allowing internal extrametricality - and as an amphibrachic line. Here it will be argued that the arte mayor exemplified by Mena's Laberinto does not allow internal extrametricality and that it is a dolnik, a syllable-stress form not usually discussed in connection with the Spanish language. At the same time as it introduces the main problems encountered by traditional approaches, this article analyses the constant and necessary characteristics of the metre used in Mena's composition, advocating the reliance on the notion of the metrical maximum. Next come some comments on other phenomena that are constant in Laberinto but not necessary in other kinds of arte mayor, and on several characteristics displayed by those other kinds but absent from Mena's work. The Conclusion offers a series of suggestions for further research into the limits of this metre.
\end{abstract}

Keywords: Spanish versification, Juan de Mena, arte mayor, dolnik, maximum

In his classic study on Spanish verso de arte mayor (higher-artistry verse), Le Gentil states that this is "une versification [...] assez compliqué, dont le secret a longtemps échappé aux critiques" = "a rather difficult versification [...] whose secret has escaped critics for a long time" (1953: 363). ${ }^{1}$ Despite the best efforts of the metrists coming after him, the nature of arte mayor has remained "obscure" (Roubaud 1971: 372).

* Author's address: Jesús M. Saavedra Carballido, Universidade de Santiago de Compostela, Rúa das Carretas 22, 3, Santiago de Compostela, 15705, A Coruña, Spain, email: jesus.saavedra@usc.es.

1 The author wishes to thank the editors - Maria-Kristiina Lotman in particular - for their patience, and the anonymous reviewers for their insightful comments and suggestions. In responding to them, every effort has been made to keep the argument as easy to follow as possible. To avoid essay-like notes, the background information concerning Spanish metrics, phonology and previous theories of arte mayor has been confined - together with all statistics to the Addenda. 
Arte mayor dominated learned Spanish verse throughout the 15th century, such that "no other long verse was ever able to establish itself" (Clarke 1964: 212). Here I shall focus on its most frequently studied variety, the one used by Juan de Mena in his allegorical work Laberinto de fortuna = Labyrinth of Fortune (finished in 1444). Mena has long been regarded the indisputable master of arte mayor, Laberinto has been called "the best poem" in this form, and, though perhaps "not the typical" example, its verse "traditionally has been considered the norm" (Clarke 1964: 167); not for nothing is arte mayor also known as verso de Juan de Mena = Juan de Mena's verse. Most conveniently, Mena’s 2376-line work represents "a consistent - and still sizeable - corpus" (Piera 1981: 102). For all of these reasons, it is a good starting point in the study of this form.

Domínguez Caparrós classifies arte mayor as an irregular form (2014: 159ff.), i.e. one that cannot be properly called free verse but whose lines, despite being metrically equivalent, display some oscillation in terms of syllable count. Though he describes arte mayor as accentual, from his account it is obvious that he does not refer to a metre regulating stresses alone, but both the syllable count and the distribution of stresses; ${ }^{2}$ this view is shared by most scholars (e.g. Duffell 1999: 60- 61, 73-74).

In an oft-quoted passage, which has served as the basis of later descriptions such as Domínguez Caparrós's, Clarke states that the "basic pattern" of arte mayor can be "roughly" represented as:

(w) s w w S (w) \# (w) s w w S (w)

As she explains, $w$ corresponds to a nonstress, $S$ to a stress and $s$ to a secondary - i.e. optional - stress; ${ }^{4}$ the hash sign represents a midline boundary rule or caesura (1964: 51). She adds:

2 Domínguez Caparrós makes it clear that the metre that he is dealing with tends to be anisosyllabic rather than isosyllabic $(2014: 45,159)$. His reference to arte mayor as accentual coincides with that of previous authors like Henríquez Ureña (2003: 171, 175, 182, 192-193, 241), who distinguishes two Spanish metres in which the number of syllables is irregular or fluctuating (within limits): one he calls amétrico (ametrical); the other, to which are mayor would belong, acentual (accentual). Actually, both are types of metrical verse: neither is what we would call free. The difference between them seems to lie in the (relative) absence or presence of an insistent rhythm based on the placement of stresses, which is less noticeable in "ametrical" verse than in "accentual" verse.

3 Clarke's notation has been adapted to the one employed in the rest of this article.

4 In Spanish, syntactic words are prosodically divided into tónicas and átonas, that is, tonic (always stressed) and atonic (usually unstressed). For more details on Spanish stress, see Section $2 \mathrm{c}$ of the Addenda. 
The caesura is movable between [the second and third] stresses, the secondary stresses are not absolutely fixed in required presence or position, and the unstressed syllables in parentheses are not absolutely fixed except that at the caesura at least one of the unstressed syllables is usually present (Clarke 1964: 51; my italics).

Clarke assumes the line to be unified (verso simple) rather than divided (verso compuesto), and this despite the caesura (1964: 57, 60, 169, 210). Her opinion is in line with other descriptions of Spanish metrical verse (for its general characteristics, see Section 2a of the Addenda). Among the "common [...] modifications of the pattern", she mentions "the use of two unaccented syllables preceding the [first] secondary stress", instead of one or none (1964: 168). Excluding the optional nonstress at line end, arte mayor lines have from eight - usually nine - to twelve syllables. ${ }^{5}$

Clarke's description is quite detailed, yet it fails to explain the syllable count, the exact distribution of stresses, the precise nature of the midline boundary and the relation between the two parts of the line. The uncertainties which surround Clarke's analysis are common to all existing accounts of arte mayor. In the course of time, to begin with, its template has been described as falling, or - more usually - as amphibrachic or rising (for previous theories of arte mayor, see Section 3a of the Addenda). To start dispelling these uncertainties, I shall take my cue from Ker and García Calvo. Ker pointed out over a century ago the affinities between Spanish arte mayor and the English metre known as tumbling verse (1899: $119 \mathrm{ff}$.). So did García Calvo more recently (2006: 1627-1628, 1640-1662). Arguably, the metre with which these two authors associate arte mayor is a dolnik - a metre that regulates the syllable count and the distribution of stresses so that strong positions will be usually realized by a stressed syllable and usually separated from each other by two or one

\footnotetext{
5 For the theoretical assumptions behind the metrical approach adopted in this article, see Section 1a of the Addenda. I shall always refer to the length of verse lines counting up to the syllable realising the last strong position, and disregarding as extrametrical the material that may follow. By doing this, I avoid the traditional Spanish terminology according to which, because of the predominance of paroxytonic lines (with one extrametrical syllable), the total number of syllables in a line is always calculated by counting up to rightmost stress (or equivalent) and adding one. If we applied this traditional system to the English iambic pentameter (a 10-position line, according to most current accounts), we would have to describe it as an 11-syllable line (cf. the Spanish term endecasílabo). The traditional system is overcomplicated, because it relies on counting and adding up when only counting is necessary; it has been criticized, but never replaced once and for all, by a number of Spanish scholars (cf. Piera 1981: 5-7; Domínguez Caparrós 2014: 62 n. 41).
} 
unstressed syllables - with a predominant but not constant ternary rhythm. Unfortunately, these two authors do not go into any details concerning the exact characteristics of the metre and its realization. What I propose to do is analyse the constant and necessary features of the verse of Laberinto by treating it as a rising dolnik made up of lines with four strong positions. ${ }^{6}$

To substantiate the dolnik interpretation, I shall examine the arte mayor used in Laberinto, ${ }^{7}$ comparing it with compositions by other Spanish authors from just before Mena's times (Alfonso Álvarez de Villasandino and Micer Francisco Imperial) to contemporary times (Ramón María del Valle-Inclán); scholars have identified some of the verses used by these authors as varieties of arte mayor, and I accept and take advantage of this identification. ${ }^{8}$

6 Dolnik is the Russian name - lately adopted in English - for the metrical form to which I am assimilating arte mayor (cf. Tarlinskaja 1993: 12; Gasparov 1996: 18-26, 175-200, 274-281; Attridge 2012; 2013: 103-111, 147-177). In English dolnik has received other names, among them loose iamb (Fabb and Halle 2008); but dolnik and loose iamb have sometimes been distinguished on statistical grounds (for example by Tarlinskaja 1992: 3, 5; 1995: 505; Hanson 2008: 380). Tarlinskaja characterizes dolnik as follows (her ictus is a strong position; ictic and nonictic positions are strong and weak, respectively; nonictic syllables are those realizing weak positions): "The regularity of stress alternation [...] is fairly consistent, so the ictic positions are, as a rule, easy to identify. However, the number of non-ictic syllables (usually unstressed or, less often, bearing lighter stresses) between adjacent ictuses may vary between one and two, and the number of syllables [...] preceding the first ictus, may be either constant, or vary from 0 to 2" (Tarlinskaja 1993: 12). As Attridge does for English dolnik (2012: 8-9 n. 15; 2013: 107-108, 154-155 n. 11), Tarlinskaja admits that a weak position between strong positions may be realized by "zero unstressed syllables", though she thinks that this only happens "in rare cases" (Tarlinskaja 1993: 13); Duffell concurs (2008: 34). In Spanish, such unrealized or void weak positions do not occur. Anisosyllabic dolnik is to be distinguished from another metre often referred to in English, again by its Russian name, as taktovik. This is an even "looser" form in which "the intervals between adjacent ictuses vary from one to three syllables" (Tarlinskaja 1993: 14; cf. Gasparov 1996: 18-26, 274-275). In English taktovik has also been identified as a kind of loose anapaest (a metre allowing 4-syllable intervals, according to Fabb and Halle 2008: 80-82); but when Piera analyses arte mayor as loose anapaest (2008), he only contemplates 3-syllable intervals.

7 I rely on the text established in Maxim P. A. Kerkhof's authoritative edition (Mena 1995). Though the text that it offers does not differ substantially from that of other editions, such as John G. Cummins's (Mena 1979), Kerkhof's is the only one that collates the variants from all known sources.

8 Navarro Tomás traces the whole history of Spanish arte mayor from the Middle Ages to the 20th century (1974: 95-98, 115-124, 225-226, 277-278, 325, 443-444, 524). Saavedra Molina (1945: 9, 18-20, 31-32, 45-46, 54-57, 65-66, 115-116), Navarro Tomás (1974: 115-117) and Clarke (1964: 69-72) agree that Villasandino was a practitioner of arte mayor. According to Saavedra Molina (1945: 18, 32, 62-63), Navarro Tomás (1974: 117), Clarke (1964: 99-151) and García Calvo (2006: 1656), so was Imperial. The basic identity between the metre of Laberinto 


\section{Constant and necessary characteristics of arte mayor in Laberinto}

It has been repeatedly said - and can be easily noticed - that the predominant rhythm in Laberinto is usually ternary (e.g. Navarro Tomás 1974: 115-116; Duffell 1999: 56; for my own figures, see Sections $4 \mathrm{~b}$ and $4 \mathrm{c}$ of the Addenda). To begin with, therefore, a convenient way of approaching the arte mayor of Laberinto is to analyse it as a rising ternary metre with four strong positions, each realized by a stressed syllable and separated by two unstressed syllables; all syllables to the right of the rightmost stress are considered extrametrical (they do not correspond to any of the metrical positions that make up the template). The only relevant variations that this metre allows are in the number of nonstresses before the first strong position (from zero to two) and of final extrametrical nonstresses (either zero or one). The template would be:

(w) (w) s w w s w w s w w s $\{x\}$

Here $s$ signals a strong position, $w$ signals a realized weak position, $(w)$ indicates an unrealized (void) weak position, and $\{x\}$ represents the optional extrametrical material.

In Laberinto, the following 12-syllable line with an oxytonic ending, i.e. without extrametrical nonstresses, realizes the ternary template quite faithfully ( $X$ marks a stress and $x$ a nonstress): ${ }^{9}$

and that of some Valle-Inclán folk-inspired compositions has been suggested by Saavedra Molina (1945: 10, 91-92) and Navarro Tomás (1974: 444), the latter of whom mentions their predominant binary rhythm. (In English there is a similar division between folk or folk-inspired dolnik, which is predominantly binary, and dolnik of learned origin, as shown by Tarlinskaja 1993: 39.)

9 I accept the way in which Kerkhof stresses words in his edition of Laberinto. This means assuming, with Piera (1981: 109), that Mena assigned stresses in much the same way as in present-day Spanish. There are some possible exceptions, mostly in proper names and cultisms, some of them adapted to fit the rhyme (cf. Lázaro Carreter 1972: 355-356, 360; Piera 1981: 141-144). In this respect, it must be borne in mind that, back then, many words of classical origin were stressed differently from now, and that the stressing of others may have been unstable, so Mena's tinkering is much less frequent than it might seem. This tallies with the idea that in Spanish verse stress wrenching is generally confined to song, to burlesque compositions and to folk-song imitations intended for recitation (Henríquez Ureña 2003: 183 n. 18, 257-258 n. 26). As Mena’s address to the "lectores"= "readers" implies (1. 1910), and as Lázaro Carreter admits (1972: 354), Laberinto was meant to be read not listened to. 
(1) Aristótiles cerca del padre Platón (1. 939) ${ }^{10}$

$\begin{array}{llllllllllll}\mathrm{x} & \mathrm{X} & \mathrm{X} & \mathrm{x} & \mathrm{X} & \mathrm{x} & \mathrm{x} & \mathrm{X} & \mathrm{x} & \mathrm{x} & \mathrm{X}\end{array}$

Since, in Spanish, paroxytonic words are far more numerous than oxytonic ones (cf. Quilis 1993: 403), few Laberinto lines have this abrupt ending; in even fewer is the stressing so regular. ${ }^{11}$ Similarly rare are 11-syllable lines (with a void weak position at the beginning) without extrametricality, like this one:

(2) Agora, respuse, conosco mejor (1. 1881)

$\begin{array}{llllllllllllll}\mathrm{x} & \mathrm{X} & \mathrm{x} & \mathrm{x} & \mathrm{X} & \mathrm{x} & \mathrm{x} & \mathrm{X} & \mathrm{x} & \mathrm{x}\end{array}$

Lines with a paroxytonic ending, i.e. with one extrametrical nonstress at the end, are more abundant. Here is an 11-syllable example:

(3) tomando castillos, ganando lugares (1. 1181)

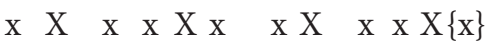

Such 11-syllable lines with extrametricality are extremely frequent. ${ }^{12}$ So much so that many commentators have considered them to reveal an ideal arte mayor

10 In addition to initial and final punctuation, I remove quotation marks and editorial diaeresis - used by editors to indicate that two contiguous vowels cannot be treated as one single syllable - from all the examples.

11 My scansions reflect all stresses corresponding to the prosodic heads of tonic words, including the head of each part of compounds (primary stresses), yet disregards all other possible stresses not corresponding to the heads of tonic words (secondary stresses). I assume that these secondary stresses are inexistent or irrelevant for Laberinto. For the rationale behind this assumption, see Section $3 \mathrm{~b}$ of the Addenda.

12 Navarro Tomás has not hesitated to scan a whole stanza of Laberinto as belonging to this type (1974: 119): “Con dos quarentenas e más de millares / le vimos de gentes armadas a punto, / sin otro más pueblo inherme allí junto, / entrar por la vega talando olivares, / tomando castillos, ganando lugares, / faziendo por miedo de tanta mesnada / con toda su tierra temblar a Granada, / temblar las arenas fondón de los mares" (stanza 148, 1l. 1177-1184). Given the presence of contiguous vowels in most lines, other scansions are of course possible. According to the figures furnished by Foulché-Delbosc (1902: 99-102), which encompass all lines in Laberinto, this kind of line represents $56.8 \%$ of the total. His analyses are not entirely reliable, as they do not have clear criteria concerning how to count syllables and what counts as the rhythm-marking element (sometimes it is stresses corresponding to the heads of tonic words; sometimes, other alleged stresses whose nature is not specified). Nevertheless, these figures suffice to direct our attention to unmistakable tendencies - in terms of syllabic length and of stressing - in Mena's arte mayor. My own calculations of line types in Laberinto can be consulted in Section 4a of the Addenda. In this case, they are largely congruent with Foulché-Delbosc's (55.2 \%). 
form corresponding to a 4-amphibrach template (the vertical bar signals the metrical boundary between consecutive feet):

w s w | w s w | w s w | w s w

Also frequent are 10-syllable lines without nonstresses at the beginning and with one extrametrical syllable at the end:

(4) sirve metales, metales adora (1. 789)

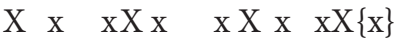

The last three are, by far, the most usual kinds of line in Laberinto. ${ }^{13}$ Another source of variation from isosyllabic ternary verse comes not from the addition and ommission of nonstresses at the extremes but from the fact that stresses are not confined to strong positions or nonstresses to weak positions. If we resist the temptation to suppress and add stresses in order to be more faithful to the alleged template, we realize how frequent these kinds of departure are. Witness the second stress in this line (I provisionally underline the syllables realizing strong positions in such a way that a ternary rhythm is somehow preserved):

(5) Dame tú, Palas, favor ministrante (1. 1125)

$\underline{X} \times \quad X \quad \underline{X} \times \underline{X} \quad \mathrm{x} \times \underline{X}\{\mathrm{x}\}$

The occurrence of unexpected stresses in weak positions is a well-known and accepted phenomenon in Spanish and in other versifications, where it receives different names (in English, for instance, Attridge calls it demotion). The inverse phenomenon, an unexpected nonstress in a strong position (Attridge's promotion), is likewise permitted. In the following line, for example, if we want to keep the four strong positions that most commentators agree on, but without adding stresses at will, we have to admit that the first strong position is realized by a nonstress:

13 According to Foulché-Delbosc (1902: 99-102), amphibrachic lines, including those without a final nonstress, amount to $63.4 \%$. Adding headless amphibrachic lines (31.4\%), without and with a final nonstress, we have over $94 \%$ of lines in Laberinto. Finally, 12-syllable ternary lines like example (1) amount to $0.1 \%$. My figures are similar ( $97.3 \%$ and $0.2 \%$ respectively). Obviously, one of the difficulties of arte mayor analysis lies in accounting for the minority of lines that remains. 
(6) introduzido por público pro (1. 1844)

$\begin{array}{lllllllllll}\underline{\mathrm{x}} & \mathrm{x} & \mathrm{x} & \underline{\mathrm{X}} & \mathrm{x} & \mathrm{x} & \underline{\mathrm{X}} & \mathrm{x} & \mathrm{x} & \underline{\mathrm{X}}\end{array}$

In this other example, the affected strong position is the third:

(7) así como príncipe legislator (1. 643)

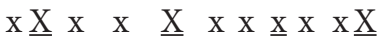

\section{From ternary verse to dolnik}

The variations observed until now are among the most frequent in Laberinto. They are not the only ones though. More troubling for the ternary and amphibrachic theory are cases like the following, in which stresses are separated by one nonstress instead of two:

(8) en Ras con aquel señor de Charní (1. 1590)

$\begin{array}{lllllllllll}\mathrm{x} & \underline{\mathrm{X}} & \mathrm{x} & \mathrm{x} & \underline{\mathrm{X}} & \mathrm{x} & \underline{\mathrm{X}} & \mathrm{x} & \mathrm{x} & \underline{\mathrm{X}}\end{array}$

One way of explaining this phenomenon, in particular within the amphibrach framework, has been to speak of a missing nonstress in the middle of the line (Piera 1981: 130; Dufell 1999: 68). From the perspective of traditional Spanish metrics, this solution has an ad hoc air. Moreover, it cannot explain the following case, where a nonstress does not seem to be missing midline (between the second and third stresses) but elsewhere (between the third and fourth stresses):

(9) aquel coraçón que si no querer (1. 894)

$$
\mathrm{x} \underline{\mathrm{X}} \times \mathrm{x} \underline{\mathrm{X}} \times \mathrm{x} \times \underline{\mathrm{X}} \times \underline{\mathrm{X}}
$$

From the perspective of a rising ternary template, it can be argued that lines without two initial nonstresses are headless, and that final nonstresses are extrametrical. From the perspective of an amphibrachic template, it has been argued that lines with an oxytonic ending are truncated, that lines beginning with a stress are headless, and that lines beginning with two nonstresses have 1-syllable initial extrametricality. The possibility of extrametricality and/or of void weak positions is thus assumed at the beginning and at the end of lines. Internally, void positions must also be allowed. 
The assumption of so many void positions in arte mayor is problematic, because in Spanish final truncation and initial headlessness are not strictly symmetrical: truncation is considered a permissible exception to the usual paroxytonic ending (cf. Domínguez Caparrós 2014: 60ff.); by contrast, headlessness is not habitually acknowledged, at least in long lines. The same can be said of initial extrametricality, which is traditionally permitted in short lines but not in long ones. As regards internal voids, the truth is that, outside song, Spanish verse does not usually permit them at all.

The dolnik solution proposed here is unusual too, yet simpler. What I suggest is treating the verse of Laberinto as a rising, 8-position form in which internal weak positions may be realized by two or one syllables and initial weak positions may be realized by two, one or - in the case of headlessness - zero syllables. Its template would be: ${ }^{14}$

$$
\text { (w) s | w s |w s | w s }\{x\}
$$

The dolnik hypothesis makes it possible to forget about void weak positions between consecutive stresses. (Later we shall see that, in addition to being simpler, this interpretation of arte mayor may also be more accurate, as it predicts lines that are absent from Laberinto but present in other compositions.) The downside is that it may complicate the identification of some strong positions in certain lines:

(10) oras silvando como dragón (1. 1965)

$$
\begin{array}{lllllll}
\underline{\mathrm{X}} \mathrm{x} & \mathrm{x} & \underline{\mathrm{X}} & \mathrm{x} & \underline{\mathrm{x}} & \mathrm{x} & \mathrm{x} \underline{\mathrm{X}} \\
\underline{\mathrm{X}} \mathrm{x} & \mathrm{x} & \underline{X} & \mathrm{x} & \mathrm{x} & \underline{\mathrm{x}} & \mathrm{x} \underline{\mathrm{X}}
\end{array}
$$

This difficulty can be solved, in some cases, thanks to the notion of the maximum. For the time being, I shall just suggest that, in order to account for the demotion of odd-numbered strong positions without manipulating the stresses and thus violating the givens of the language, the metrical template of arte mayor should be conceived of as containing two cola and two kinds of

14 The idea that weak positions may be realized by two or one syllables is taken from such disparate authors as Attridge (1982; 2012; 2013), Chisholm (1995) and García Calvo (2006: 1640-1662). Alternatively, it would be possible to posit the template: (w) (w) s $|\mathrm{w}(\mathrm{w}) \mathrm{s}| \mathrm{w}(\mathrm{w})$ $\mathrm{s} \mid \mathrm{w}(\mathrm{w}) \mathrm{s}\{\mathrm{x}\}$, where every $s$ is realized by one syllable, every $w$ after $s$ is also realized by one syllable, and any other $w$ is optionally realized by one syllable or left unrealized. My notation has the advantage of less cumbersome and of requiring not two but only one type of $w$ when dealing with dolnik without headlessness. 
strong positions, only some of which (the second and fourth) function as the head and rightmost limit of a colon (the hash sign marks the frontier between initial and final cola):

(w) s | w s \# w s | w s $\{x\}$

To test the dolnik hypothesis, I shall apply it to lines whose prosodic analysis is relatively straightforward. The presence of contiguous vowels in Spanish verse can result in considerable variation in the syllable count and in the determination of the rhythm of the line, because in these cases all vowels or just one may be taken into account (cf. Piera 1981: 8; 2008: 95ff.). For this reason, I try to avoid instances with vocalic sequences (as advised by Clarke 1964: 105). Further, in Kerkhof's edition of Laberinto (Mena 1995), there are words written with and without $h$, such as (h)avía = there was/were and (h)ermanos = brothers, a variation that may or may not affect the syllable count. In view of this, I also leave out of my analysis lines with $h$ between vowels. For good measure, I also exclude lines with elided vowels (marked with an apostrophe 'by Kerkhof). These exclusions should make it possible to determine more accurately the permissible line lengths. (The complete list of lines meeting these conditions can be found in Section 4a of the Addenda. $)^{15}$

On the face of it, in the arte mayor of Laberinto colon-final strong positions are realized by a stress, while other strong positions are less strictly constrained: the syllables realizing them can be stressed or not. Weak positions are even less constrained: they can be realized by two or one syllables, whether stressed or not, or even - at the beginning - by zero syllables. Each colon is realized by between four and six syllables. Extrametrical syllables cannot be stressed.

This template and these realization rules suffice to explain all the examples given so far. In practice, the verse of Laberinto seems to consist in long unified lines; colon-final strong positions must be realized by a stress. The syllable count and the distribution of compulsory stresses are as follows: after a stretch of between three and five syllables, every line contains a stress realizing a colon-final strong position; then, after another interval of between three and five syllables, there is one more stress realizing the rightmost strong position. In its reliance on colon-final anchor-points, coupled with the frequent

\footnotetext{
15 I assume that the treatment of contiguous vowels in 15th-century verse was as it is today, and that this treatment is the same throughout the line (pace Piera 1981: 9, 134), but not across lines (cf. Piera 1981: 34). For the problem of contiguous vowels in Spanish metrics, see Section $2 \mathrm{~b}$ of the Addenda.
} 
disregard of stresses in other parts of the line, arte mayor would not differ from other Spanish long metres. ${ }^{16}$

For the sake of convenience, all instances of arte mayor can be labelled through a two-figure formula representing the number of syllables in each colon. The examples quoted so far belong to the following types:

6\#6: example (1)

5\#6: examples (2), (3), (7)

4\#6: examples (4), (5), (6)

5\#5: examples (8), (9)

4\#5: example (10)

The frequencies of line types observed in this group are largely congruent with those found in Laberinto as a whole (see Section $4 \mathrm{a}$ of the Addenda). Judging from the examples, it can be surmised that the final colon cannot be realized by fewer syllables than the initial one, which itself cannot be realized by fewer than four syllables (even when there is headlessness). Laberinto excludes a construct like the following, which can only be scanned as $6 \# 5$ and yet reads quite well:

(a) *esperaba lograr mejor resultado $\mathrm{x} \times \underline{X} \times \mathrm{x} \underline{\mathrm{X}} \# \mathrm{x} \underline{\mathrm{X}} \mathrm{x} \times \underline{\mathrm{X}}\{\mathrm{x}\}$

As examples (7) and (10) show, between the stress realizing the first colon-final strong position and the next stress sometimes there can be three or more syllables instead of the two or one that Kerkhof stipulates (Mena 1995: 31, 110). The following $5 \# 6$ lines display similar departures from a ternary rhythm:

16 Colon-end (including line-end) stresses are thus the foundation of whatever stress rhythm arte mayor lines may have. It must be noted that, in Laberinto, it is precisely at colon-end (particularly at line-end, where there is rhyme) that most of the (few) unusual stressings that can be determined with certainty occur. An example: "tú, Penelope, la qual en la tela" (1. 510), where the proper noun Penelope must be pronounced as a paroxytone ( $\mathrm{X} \times \mathrm{x} \mathrm{X} \# \mathrm{x} \ldots$...) not as a proparoxytone, as is done today, in order to prevent the two cola from being incorrectly realized by three and seven syllables, respectively. Compare it with "nueva Penélope aquésta por suerte" (l. 622), where editors treat the noun as proparoxytonic. 
(11) vi despojadores e vi despojados (1. 1235) $)^{17}$

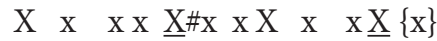

(12) en las baxas artes que le da Minerva (1.474)

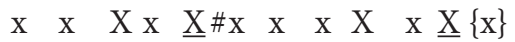

On this occasion I have only underlined the stresses realizing colon-final strong positions, because it is not always easy to determine which syllables correspond to other strong positions. ${ }^{18}$ Both these examples contain a stressed monosyllable that appears earlier or later than expected (in the initial and final colon, respectively) and that cannot be interpreted as realizing a strong position, but only as being displaced (i.e. omitted at some point and added at some other).

As shown by the final cola in these other $5 \# 6$ lines, the displaced stresses can also belong to polysyllables:

(13) primero fallaron, gentes amonitas (1. 284)

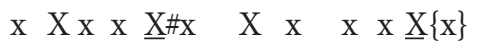

17 If the metre that I am positing were not rising but falling, the template would be $\{x\} \mathrm{s} \mathrm{w} \mid \mathrm{s}$ $\mathrm{w} \# \mathrm{~s} \mathrm{w} \mid \mathrm{s}(\mathrm{w})$, the initial colon would be realized by between three and four syllables up to the rightmost stress, and the final colon by between four and six syllables, i.e. the whole line would be realized by between seven and ten syllables up to the rightmost stress; truncation and 1- or 2-syllable initial extrametricality would be necessary to account for many lines in Laberinto. This approach only works if extrametrical stresses are accepted at the beginning of 5- and 6-syllable cola, as at the beginning of example (11); that is why the falling (in particular dactylic) hypothesis has been criticized by Piera (1981: 122-127). As it requires final extrametricality (as in other Spanish metres) instead of initial extrametricality, the rising version is more congruent with counting metrical positions from left to right up to the rightmost stress, precisely what should be generally done - as already suggested - with Spanish metres.

18 In cola realized by six syllables, the placement of the internal strong position is clear, and a ternary rhythm realizes the metre more faithfully than a binary one. If consecutive strong positions are ruled out, in cola realized by four syllables the placement of the internal strong position in final cola is also clear: it cannot be at the beginning, so in this case a binary rhythm is more faithful to the template; in initial cola, if we accept headlessness, the placement of the first strong position is clear when the first two syllables are a stress and a nonstress (s w s \#, with headlessness) or a nonstress and a stress (w s w s \#), but less so when both are stresses or nonstresses. Finally, in cola realized by five syllables, the placement of the internal strong position cannot always be known with certainty beyond the fact that it must two or three syllables before the colon-final strong position. If we marked this internal strong position always according to a ternary rhythmic norm, we would be artificially reinforcing what is only a statistical tendency, making it more normative than it really is. 
(14) e lo que queremos menos acabamos (1.232)

$\begin{array}{lllllll}\mathrm{x} & \mathrm{x} & \mathrm{x} & \underline{\mathrm{X}} \# \mathrm{x} \quad \mathrm{X} & \mathrm{x} & \mathrm{x} & \mathrm{x}\end{array} \underline{\mathrm{X}}\{\mathrm{x}\}$

What these two lines have in common is that a nonstress belonging to a polysyllable realizes a strong position while a stress in the same word appears in a weak position. This is a phenomenon that, from the perspective of other metrical traditions, can be taken to invalidate the dolnik explanation of Mena's arte mayor (and also, for that matter, the ternary and amphibrachic explanations - though not the taktovik explanation, which the syllable count makes nevertheless unlikely). It must be borne in mind, however, that the practice of misplacing disyllabic and longer words is common currency in Spanish verse. ${ }^{19}$ Such cases are relatively frequent in Laberinto (though not at colon end): a nonstress realizing a strong position can be next to a stress belonging not to a monosyllable (e.g. 1. 474, example (12)) but to a polysyllable (e.g. the paroxytone mesmo = same in 1. 815: "e madre del fi\#jo de su mesmo pa\{dre\}", whose final colon scans as ...\# $\mathrm{x} \times \mathrm{x} \mathrm{X} \times \underline{\mathrm{X}}\{\mathrm{x}\}$ ), and both the nonstress and the stress can belong to the same word, which therefore thwarts metrical expectations not only on one occasion, but on two or more, and not only within one foot (e.g. 1. 284, example (13); 1. 232, example (14)), but even across feet (e.g.

19 Misplaced polysyllables do not detract from the metrical correctness, for example, of the following lines by the 16th-century author Garcilaso de la Vega, which realize a binary 10-position template of the a maiore type (6\#4): "Cómo deste lugar hice mudanza" (X $\underline{\mathrm{x}} \mathrm{X} \underline{\mathrm{x}} \times \underline{\mathrm{X}} \# \mathrm{X} \underline{\mathrm{x}} \times \underline{\mathrm{X}}$ $\{\mathrm{x}\}$ ), in which all stresses save those realizing colon-final strong positions realize weak positions and correspond to paroxytonic disyllables, while all nonstresses in the misplaced words occupy strong positions; "él olvidará presto la braveza" ( $\mathrm{X} \underline{\mathrm{x}} \mathrm{x} \underline{\mathrm{x}} \mathrm{X} \underline{\mathrm{X}} \# \mathrm{x} \underline{\mathrm{x}} \mathrm{x} \underline{\mathrm{X}}\{\mathrm{x}\})$, with the oxytonic tetrasyllable olvidará $=$ will forget realizing the sequence s w s w; "recogido le llevan, alegrando" $(\mathrm{x} \underline{\mathrm{x}} \underline{\mathrm{X}} \mathrm{x} \underline{\mathrm{X}} \# \mathrm{x} \underline{\mathrm{x}} \times \underline{\mathrm{X}}\{\mathrm{x}\})$, with the paroxytonic tetrasyllable recogido = gathered realizing the sequence w s w s (Vega 2001: 171, 195, 244). Despite these (permissible) sources of variation, in Vega's hands the rhythm of the 10-position metre is overwhelmingly binary (cf. Duffell 1999: 38-39). In English dolnik, misplaced polysyllables are rare but do not result automatically in incorrect lines. As in other English metres, initial and final stresses in polysyllables can appear after a metrical, syntactic or prosodic boundary (cf. Jakobson 1966: 363-364), but also in other contexts (for examples outside dolnik, cf. Kiparsky 1977; Attridge 1982: 265-275; Wright 1988: 198-199). Take this dolnik line by Yeats: "The days chatter and scream" (from "The Tower"; qtd. Tarlinskaja 1993: 102); it realizes the template w s w s w s \#. The paroxytonic disyllable chatter realizes either the second w s (Tarlinskaja's interpretation: $\mathrm{x} \underline{\mathrm{X}} \mathrm{X} \underline{\mathrm{x}} \mathrm{x} \underline{\mathrm{X}}$ ) or the second $\mathrm{s}$ $\mathrm{w}$ (in which case the preceding $w$ is left unrealized; this would probably be Attridge's preferred scansion, with the void marked as $[\mathrm{x}]: \mathrm{x} \underline{\mathrm{X}}[\mathrm{x}] \underline{\mathrm{X}} \mathrm{x} \mathrm{x} \underline{\mathrm{X}})$. The same can be said of the paroxytonic disyllable started in "That was how the grief started to melt" (... $\underline{\mathrm{X} X} \underline{\mathrm{x}} \mathrm{x} \underline{\mathrm{X}}\{\mathrm{x}\}$ or ...x $\underline{\mathrm{X}}[\mathrm{x}] \underline{\mathrm{X}}$ $\mathrm{x} x \underline{X}\{\mathrm{x}\}$, from Frost's “The Thatch"; qtd. Tarlinskaja 1993: 102). In Spanish, the assumption that voids play no role leaves us with Tarlinskaja's reading, which does not differ much from my own interpretation of similar realizations in Laberinto. 
the oxytone derribar = knock down in 1. 2119: "Basta que pu\#do derribar al $\mathrm{u}\{$ no\}", whose final colon scans as ...\# $\mathrm{x} \times \mathrm{x} \mathrm{X} \times \mathrm{X}\{\mathrm{x}\}$ ). (For the specific figures of misplaced polysyllables, see Section $4 \mathrm{~d}$ of the Addenda; cf. the discussion and Appendixes in Duffell 1999: 74-78, 89-90.)

In the following case there are zero syllables between stresses belonging to different cola (the relative lengths of cola observed until now serves to disambiguate the line as $5 \# 5$ rather than $6 \# 4)$ :

(15) e sobre partir tales discordanças (1. 2034)

$\begin{array}{lllllll}\mathrm{x} & \mathrm{x} & \mathrm{x} & \underline{\mathrm{X}} \# \mathrm{Xx} & \mathrm{x} \mid \mathrm{x} & \underline{\mathrm{X}}\{\mathrm{x}\}\end{array}$

What sets this example apart from the preceding ones is that the displaced disyllable tales $=$ such can be interpreted as fitting snugly in one single weak position, hence as disrupting the rhythm just once - through demotion. (By contrast, the strong position would be realized by the first nonstress of discordanças $=$ discords - a case of promotion.) Leaving aside such cases of comfortable fit (another example would be the oxytone primer $=$ first in the initial colon of 1. 371: "que del primer fran\#co que tovo corona", whose initial colon can be scanned X X|x X $\underline{X} \#$...), in Laberinto all the displaced polysyllables appear in final cola; there is even the possibility of misplacing several polysyllables (as in 1. 1239: "e vi dos estre\#mos fechos una par\{te\}", whose final colon scans as ...\# $\mathrm{XXXXX}$ X $\underline{\mathrm{X}}\{\mathrm{x}\}$, where the paroxytone fechos $=$ made realizes a weak and a strong position while the paroxytone una = one fits in a weak position). A possible explanation is that final cola are often longer, affording greater possibilities to deviate from the template, and that authors simply take advantage of them; to this it can be added that in the final colon the need to be strictly regular is not so pressing after the metre has been fairly faithfully indicated by the rhythm in the initial part of the line.

All this indicates that in arte mayor a ternary rhythm may prevail, but it is far from constant or necessary: stresses other than the ones at colon end are frequent, but they are not required; when they do occur, they often go against the predominant ternary rhythm, even if they belong to polysyllables. ${ }^{20}$ As a result, we even find lines with a binary rhythm throughout:

(16) Echate, dixo, non te fazen guerra (1. 1995)

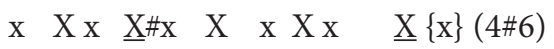

20 The pressure of the metre - and of the rhyme - over the author's language, highlighted by Lázaro Carreter (1972: 356), occasionally shows in the form of wrenched stresses; but it must be remembered that some of the linguistic peculiarities of Laberinto that this scholar attributes 


\section{Introducing the maximum}

The rules given so far cover most lines in Laberinto. However, they cannot explain some instances in which colon-final strong positions are realized by nonstresses (given the scarcity of lines without contiguous vowels, in some of the following examples I put that restriction aside, scanning only the relevant part):

(17) el ánima contra la falsa fortuna (1. 1554)

$\mathrm{x} X \times \mathbf{x} \underline{\mathrm{x}} \#$ x $\mathrm{x} X \mathrm{x} \times \underline{\mathrm{X}}\{\mathrm{x}\}(5 \# 6)$

(18) Ca un condestable armado, que sobre (1. 2113)

$$
\ldots \quad X \quad x \quad x \quad \underline{x}\{x\}
$$

In these two lines (in which the underlined $x$ indicates a nonstress realizing a strong position) the relevant atonic words are disyllabic. This is not a necessary condition: the distribution of cola in the following example is ambiguous, but whether we scan the initial colon as ending with los $=$ those or with que = whom its rightmost word is an atonic monosyllable:

(19) a fijos de los que libró del desierto (1. 1244)

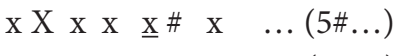

$\mathrm{x} X \mathrm{X} \quad \mathrm{x} \quad \mathrm{x} \quad \underline{\mathrm{x}} \# \ldots(6 \# \ldots)$

When analysing them, these nonstresses should not receive any emphasis, lest we go back to the old practice of stress manipulation. It is clear, then, that in Laberinto some colon-final strong positions are realized by nonstresses which can belong to both monosyllables and disyllables (a relatively rare yet important phenomenon that recurs throughout the history of Spanish metrical verse). It is simply not true that all colon-final nonstresses in Laberinto correspond to a "monosyllable", as Piera states (1981: 140).

to the influence of the metre also appear in Mena's prose (cf. Cummins in Mena 1979: 43). The fact that Mena does not always insist on a regular ternary rhythm does not prevent performers from regularizing it as they please. Obviously, nothing precludes a performance of Mena's arte mayor with four perceptible stresses, as evenly spaced as possible, in all lines. However, this imposed regularity cannot form the basis of metrical analysis: as soon as it has more than two syllables, any line - of prose and of verse, whether metrical or free - can be performed with a perfect ternary rhythm (but then it can also be performed with a binary movement). The difference between strict ternary metres and other kinds of verse - dolnik included - lies elsewhere: not in the performance but in the rhythm that is phonologically determined. 
Either we declare the last three examples to be incorrect, or we find a way to accommodate colon-final atonic words within our rules. I shall try to do the latter by adopting the notion of the metrical maximum, a kind of syllable that metrical rules recognize as particularly salient (i.e. a metrified stress), banning it from (certain) weak positions and/or requiring it in (certain) strong positions (for the history of the notion of the maximum, see Section $1 \mathrm{~b}$ of the Addenda). I suggest that in Laberinto colon-final strong positions are realized by maxima which need not be stressed. ${ }^{21}$

The first step towards a fitting definition of the maximum is to recognize that in Laberinto some unstressed syllables can perform this role, but not all. Judging from what we have just seen of Mena's arte mayor, the only nonstresses that count as maxima belong to what Spanish phonologists consider atonic words (palabras átonas), never to tonic words (palabras tónicas). This excludes constructs like the following, in which a colon-final strong position is realized by the last nonstress (indicated by an underlined $x$ ) of a tonic proparoxytone: ${ }^{22}$

(b) *los otros estaban pensándoselo

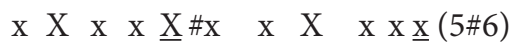

(c) *las grandes hazañas históricas

$$
\mathrm{x} \quad \mathrm{X} \quad \mathrm{x} \quad \mathrm{x} \underline{\mathrm{X}} \# \mathrm{\#} \quad \mathrm{x} \quad \mathrm{X} \mathrm{x} \underline{\mathrm{x}}(5 \# 5)
$$

The phonological reason for this exclusion lies in the syntactic relations of dependence into which Spanish words enter when combined with each other, affecting their prosody in such a way that atonic words do not receive stress in most contexts. Hualde states that these words, "like all other words, have a syllable that is designated as head of the word" (Hualde 2009: 202). Monosyllabic words, whether tonic or atonic, only have one syllable, which functions as its prosodic head; in simple polysyllabic words, tonic as well as atonic, only one

21 More generally, I would suggest that the rightmost (strong) positions of all short unified lines in Spanish have to be realized by maxima. The same rule applies to the rightmost (strong) positions of the cola that make up long unified lines and to the rightmost (strong) positions of the hemistichs making up divided lines (cf. Domínguez Caparrós 2014: 49).

22 This kind of realization at line end is permitted in languages such as English (cf. Attridge 1982: 166-167; Tarlinskaja 1987: 66, 80, 178, $181 \mathrm{ff}$.). Notice that, if the basis for the metrical analysis of Laberinto were the performance, it would not be possible to find a reason for the absence of nonheads in colon-final strong positions: if the mere addition of postlexical stresses sufficed to render nonstresses of tonic polysyllables fit for these positions, their failure to appear there would be impossible to explain. 
of the syllables can be the head. In tonic words, the head corresponds to a stress, but in atonic words the head usually corresponds to a nonstress: it only "receives stress when the [atonic] word is cited, nominalized or focalized", to name but a few suitable contexts (202).

In this article, it will be assumed that every syntactic word and every half of a compound have one head, which in speech may correspond to a stress or not. It will be further assumed that in Laberinto only some heads can be maxima, hence not all heads can realize colon-final strong positions. For the arte mayor of Laberinto, I would suggest that every head of a tonic word qualifies as a maximum, and that so does every head of an atonic word not immediately followed by the head of a tonic word within the same line (in divided lines, within the same half-line). This is one of the reasons why example (6), repeated here for the sake of convenience, cannot be scanned as 6\#4, but only as $4 \# 6$ (from now on, the signs $X$ and $x$ will indicate maxima and nonmaxima):

(6’) introduzido por público pro (1. 1844)

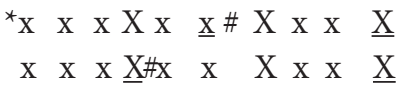

For the same reason, the following construct cannot be a Laberinto line of the 5\#5 kind, as no amount of stress manipulation can make the atonic conjunction que = that realize the strong position at the end of the initial colon:

(d) ${ }^{\star}$ fenómenos que no comprenderemos

$\begin{array}{lllllllllll}\mathrm{X} & \mathrm{X} & \mathrm{x} & \mathrm{x} & \underline{\mathrm{x}} & \# \mathrm{X} & \mathrm{x} & \mathrm{x} & \mathrm{x} & \underline{\mathrm{X}} & \mathbf{x}\}\end{array}$

The explanation is not the unusual placement of the adverb no = not in a weak position - a phenomenon that Spanish metres permit, as we have seen - but the fact that (the head of) que is somehow overshadowed by the (head of) the tonic word that follows it: unlike no, the monossylable que is not a maximum. ${ }^{23}$

23 My definition of maxima takes into account all primary stresses (stresses corresponding to the heads of words, including the head of each part of compounds) and disregards all secondary stresses. That said, the proposed definition is still pretty generous. Notice, to begin with, that a compound like vilmente $=$ vilely in 1.809 of Laberinto has two maxima: "Vimos en uno vilmente abrazados" (X x x $\underline{\mathrm{X}} \# \mathrm{x}$ X X...). Also, a stressed maximum can be immediately followed by another one belonging to a different word in the same line, as in "lavandera que no llore de pena" ( $\mathrm{x} \times \mathrm{X} \times \mathrm{x} \underline{\mathrm{X}} \# \mathrm{X} \mathrm{x} \times \underline{\mathrm{X}}\{\mathrm{x}\}$, a 10-position line of the a maiore, 6\#4 type, in Góngora 1985: 220). Likewise, an unstressed maximum can be immediately followed by another unstressed maximum: witness the realization of the position at the end of the initial colon of 1.1437 of Laberinto, scanned as either "tanto que los \# que de allí pelea\{van\}" (X X X $\underline{X} \# \ldots, 4 \# 5$ or $4 \# 6$ 
In the following $5 \# 6$ example the first head of the compound malamente $=$ badly acts as a maximum, but the head of the preceding atonic word que does not:

(20) e los matemáticos que malamente (1. 1031)

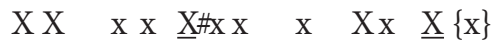

As in this line, usually there are more maxima than stresses. This happens even in some of the lines discussed before, including those in which colon-final positions are realized by (syllables of) atonic words; all of those lines can be rescanned accordingly (extrametrical syllables are never heads so they cannot be maxima):

(7’) así como príncipe legislator (1. 643)

$\mathrm{x} X \quad \mathrm{X} \quad \mathrm{x} \quad \underline{\mathrm{X}} \# \mathrm{\#} \times \mathrm{x} \times \mathrm{x} \quad \mathrm{x} \underline{\mathrm{X}}$

(8’) en Ras con aquel señor de Charní (l. 1590)

$\begin{array}{llllllllllllll}\mathrm{x} & \mathrm{X} & \mathrm{X} & \mathrm{x} & \underline{\mathrm{X}} & \# \mathrm{x} & \mathrm{X} & \mathrm{X} & \mathrm{x} & \underline{\mathrm{X}}\end{array}$

(9’) aquel coraçón que si no querer (1. 894)

$\mathrm{x} \quad \mathrm{X} \quad \mathrm{x} \times \underline{\mathrm{X}} \quad \# \mathrm{X} \quad \mathrm{x} \quad \mathrm{X} \quad \mathrm{x} \underline{\mathrm{X}}$

(10’) oras silvando como dragón (1. 1965)

$\mathrm{X} \mathrm{x} \quad \mathrm{x} \quad \underline{X} \# \mathrm{x} \quad \mathrm{X} \quad \mathrm{x} \quad \mathrm{x} \underline{\mathrm{X}}$

(12') en las baxas artes que le da Minerva (1.474)

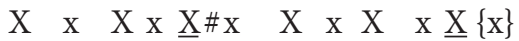

type) or "tanto que los que \# de allí pelea\{van\}" (X x X X $\underline{X} \# \ldots, 5 \# 5$ or $5 \# 6$ type). Further, an unstressed maximum can be preceded by a stressed maximum, as in "Allí vi de \# Pigmalión el herma\{na\}" (a $4 \# 6$ arte mayor line, in Santillana 2003: 346). Notice also that, if we admitted that Laberinto contains divided lines, construct (d) would create no difficulty: $\mathrm{X}$ X x $\underline{\mathrm{X}}+\mathrm{X} \times \mathrm{x} \times$ $\underline{\mathrm{X}}\{\mathrm{x}\}$ (the + sign indicates an epic caesura). Finally, notice that my account does not make the presence of maxima depend on punctuation. To be sure, punctuation can be a clue to prosody and it often reminds us of such important yet often overlooked prosodic phenomena as the preservation of stress in atonic words placed at the end of intonational phrases (e.g. before a parenthetical break). However, punctuation depends on writing conventions and on editorial practices, which, even within the same language, vary from period to period, from area to area, and sometimes from person to person. This is enough reason to ignore it in analysis. 
(14') e lo que queremos menos acabamos (1. 232)

$\mathrm{XX} \quad \mathrm{X} \quad \mathrm{x} \underline{\mathrm{X}} \# \mathrm{x} \quad \mathrm{X} \times \mathrm{x} \quad \mathrm{x} \underline{\mathrm{X}}\{\mathrm{x}\}$

(15') e sobre partir tales discordanças (1. 2034)

$\begin{array}{llllllll}X & \mathrm{x} & \mathrm{x} & \underline{X} \# \mathrm{Xx} & \mathrm{x} & \mathrm{x} & \underline{\mathrm{X}}\{\mathrm{x}\}\end{array}$

(17’) el ánima contra la falsa fortuna (1. 1554)

$\begin{array}{lllllllllll}\mathrm{X} & \mathrm{x} & \mathrm{x} & \underline{\mathrm{X}} & \# \mathrm{x} & \mathrm{x} & \mathrm{X} & \mathrm{x} & \mathrm{x} & \underline{\mathrm{X}}\{\mathrm{x}\}\end{array}$

(18') Ca un condestable armado, que sobre (1. 2113)

$\ldots X \times \quad X \quad \underline{X}\{$

(19') a fijos de los que libró del desierto (1. 1244)

$\mathrm{x} \quad \mathrm{Xx} \quad \mathrm{X} \underline{\mathrm{X}} \quad$ \# $\mathrm{X} x \quad \mathrm{X} \quad \ldots$

$\begin{array}{llllll}\mathrm{X} & \mathrm{Xx} & \mathrm{X} X & \underline{\mathrm{X}} \# \mathrm{X} & \mathrm{X} & \ldots\end{array}$

Signalling maxima makes it easier to appreciate why, in contrast to (d) above, the following construct is correct (here the atonic que is a maximum):

(e) fenómenos que jamás comprendimos

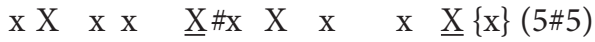

The syllable count, the realization of the colon-final strong positions, and the syllabic relation between cola - all of these elements comply with the rules given so far.

\section{Midline metrical boundary (caesura)}

Now that the syllable count and the realization of strong and weak positions in Laberinto are clearer, it is necessary to elucidate the relation of linguistic boundaries to the template.

When confronted with lines whose rightmost word is atonic, such as (18'), the notion of the maximum and the acceptance of unstressed maxima make it unnecessary to assume, as Piera does (1981:211-216), that line ends in the domain of metre necessarily translate into phrase boundaries in the realization. What makes enjambment possible is the fact that, contrary to Piera's argument, metre does not automatically introduce a systematic "line-phrase correspondence" at the end of all lines (Piera 1981: 216; cf. Piera 2003a); and 
neither is there, of course, any line-internal colon-phrase correspondence, as he further claims (Piera 2003b). Unless we are willing to violate the givens of the language, we must recognize that the lowest line boundary in Laberinto is above the syllable but below the phrase: it operates between syntactic words, whether tonic or atonic. Examples (17') and (19') suggest that the same happens with colon boundaries inside lines.

In view of the lines scanned so far, we can therefore add one more element to our account of arte mayor: between the syllables realising the second and third strong positions, as between lines, there must be some kind of linguistic boundary. The existence of a metrical rule explicitly regulating such boundaries is rejected by Piera, at least inside lines (Piera 1981: 119-121). However, the examples analysed indicate that the syllable realizing the last strong position of the initial colon and the syllable realizing the first strong position of the final colon cannot belong to the same syntactic word.

Due to the exclusion of 8-syllable lines, Laberinto does not present lines in which the first strong position of the final colon is unequivocally realized by the last nonstress of a proparoxytone (as in this $4 \# 4$ construct: * "Muchos fenó\#menos | extra\{ños\}", scanned as X x x $\underline{X} \# \times \mathrm{x} \mid \mathrm{x} \underline{\mathrm{X}}\{\mathrm{x}\})$. Neither does Mena's work contain lines in which the last word of the initial colon presents more than two nonstresses at the end (as in this $5 \# 6$ construct: * "estaban lleván\#doselos $\mid$ regala $\{$ dos $\}$ ”, scanned as $\mathrm{x}$ X x x $\underline{\mathrm{X}} \# \mathrm{x} \times \mathrm{x} \mid \mathrm{x} \times \underline{\mathrm{X}}\{\mathrm{x}\})$. The former absence might be just a stylistic preference of Mena's, and the latter might be due to the scarcity of such words in the language. Yet the fact is that in lines without contiguous vowels most straddling proparoxytones end in 6-syllable cola (see Section 4a of the Addenda); thus they necessarily fall just short of realizing a strong position in the final colon, as in this example:

(7”) así como príncipe legislator (1. 643)

$\mathrm{x} X \mathrm{X} \quad \mathrm{x} \quad \underline{\mathrm{X}} \# \mathrm{x} \times \mathrm{x} \quad \mathrm{x} \mid \mathrm{x} \times \underline{\mathrm{X}}$

In lines with contiguous vowels the situation is similar: the colon in which straddling proparoxytones end always allows - and frequently demands a 6-syllable interpretation. Finally, while in other Spanish verse compounds can straddle two cola and two lines, ${ }^{24}$ Laberinto contains no such cases

24 The two stressed maxima in a compound can appear in different lines and in different cola within the same line. The possibility has been exploited, for example, by Luis de León and Luis de Góngora. As regards the former, "Y mientras miserable- / mente se están los otros abrasan \{do\}", are a 6-position line and a 10-position line straddled by the 2-maximum adverb miserablemente $=$ wretchedly, whose first maximum realizes the rightmost strong position of 
(cf. Duffell 1999: 71-72). All things considered, I tentatively include a compulsory midline boundary rule, of the kind explained, among the realization rules of arte mayor.

\section{Beyond metrical correctness?}

The characteristics of Mena's arte mayor in Laberinto that I have identified as constant and necessary are the following: two rising cola, each with two strong positions; extrametricality aside, each colon is realized by four to six syllables; as in other dolnik, every strong position is realized by one syllable and every internal weak position by one or two; colon-final strong positions must be realized by maxima, whether stressed or not; both cola are kept distinct by a midline boundary rule, such that the syllables realizing the last strong position of the initial colon and the first strong position of the final colon cannot belong to the same syntactic word, in spite of which the lines can be said to be unified; unusually for Spanish metres, headlessness is permitted (but only as long as the initial colon is realized by at least four syllables); the final colon cannot be shorter than the initial one, so it must be realized by at least five syllables; extrametricality only appears at line end, and it is confined to one nonmaximum, so proparoxytonic line ends and extrametrical atonic words are not tolerated.

In Kerkhof's edition of Laberinto there are only two lines without contiguous vowels that fail to comply with these rules:

(21) * par en el ánimo, non en la fortuna (1. 1563)

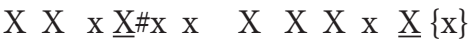

$$
\begin{aligned}
& \mathrm{X} X \quad \mathrm{X} \underline{\mathrm{X}} \mathrm{x} \times \mathrm{X} \quad \mathrm{X} \# \mathrm{X} \mathrm{x} \underline{\mathrm{X}}\{\mathrm{x}\}
\end{aligned}
$$

(22) *ramo ninguno non avrá menester (1.224)

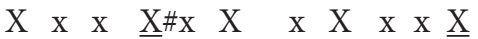

$$
\begin{aligned}
& \mathrm{X} \quad \mathrm{x} \quad \mathrm{x} \quad \underline{\mathrm{X}} \mathrm{x} \underline{\mathrm{X}} \# \mathrm{x} \mathrm{X} \mathrm{x} \times \underline{\mathrm{X}}
\end{aligned}
$$

Line 1563 is of the hypothetical $4 \# 7$ or $7 \# 4$ type. In either case, it is incorrect because there can be no 7-syllable cola. Line 224 also has two possible scansions: as either $4 \# 7$ or $6 \# 5$. The former is incorrect for the same reason.

the first line (León 2011: 74). As regards the latter, "y al fin ambos igual\#mente ayuda\{dos\}" is a 10-position line (of the a maiore, 6\#4 type) in which the 2-maxima adverb igualmente = equally, whose first maximum realizes the rightmost strong position of the initial colon, straddles both cola (Góngora 1985: 53). 
According to the latter scansion, the division into cola goes against the phrasal movement of the line. Nevertheless, this does not make the scansion incorrect (we have already seen that the only boundary required between cola is placed between two syntactic words, not necessarily tonic or phrase-final). It is incorrect simply because the final colon cannot be shorter than the initial one.

Both lines are correct if we accept the occurrence of internal extrametricality (of two and one syllables, respectively); this means accepting the occasional combination in Laberinto of unified lines (the norm) and divided lines (with possible internal extrametricality, i.e. made up of different hemistichs, here separated by the + sign that indicates epic caesura): "par en el á $\{$ nimo $\}$, + non en la fortu\{na\}" (of the $4+5$ line type) and "ramo ningu\{no\} + non avrá menester" (4+6). It could be argued that, if such combinations were possible, it would be strange for Mena to employ them so rarely. However, there is also line 939 example (1) - of a type which is equally rare (6\#6). The difference is that this line does not present any textual alternatives turning it into something more usual, whereas lines 1563 and 224 can be amended into metrical correctness with a different selection of manuscript variants. Thus we can get, for example, the lines "par en el á\#nimo, non la fortu\{na\}" (4\#6) or "par en el á\#nimo, no en la fortu\{na\}" (4\#6), and "ramo ningu\#no no avrá menester" (4\#6). ${ }^{25}$

Some lines with contiguous vowels are also dubious. The correctness of the following example depends on treating fue as a disyllable; all other scansions are incorrect (the $o$ indicates a vowel that does not count metrically inside the line): ${ }^{26}$

(23) desque Juba les fue prepotente (1.400)

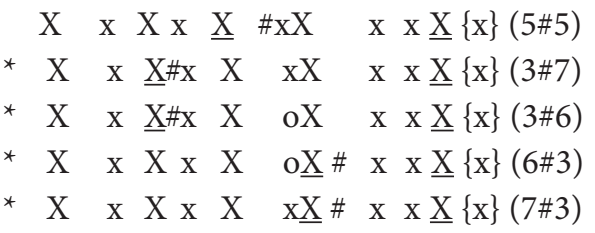

25 The two lines would also be metrical with other variants. The point here is not so much to choose the right version from the point of view of the manuscript tradition as to show that the scribes themselves may also have had doubts about the correctness of the readings eventually chosen by Kerkhof, opting for something more regular instead.

${ }_{26}$ In the case of contiguous vowels, the ones marked as metrically invisible are the higher (cf. Navarro Tomás 1967: 27, 66-73, 156, 161 ff.; but cf. 151); in the case of vowels that are identical in this respect, I mark as invisible the weaker ones (unstressed as opposed to stressed); finally, in the case of identical vowels in this respect too (stressed or unstressed), I mark as invisible the ones to the left. Invisible vowels do not count for the determination of maxima; in other words, maxima are determined after marking invisible vowels, as if they were not there. 
An alternative version, present in some sources and whose metrical correctness is beyond doubt, reads: "desde que Ju\#ba les fue prepoten\{te\}" (4\#6).

This other line is incorrect unless we interpret quieres as a trisyllable:

(24) de los passados, si quieres ver espanto (1.483)

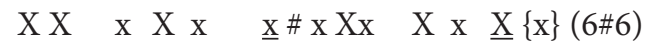

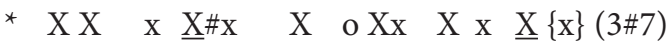

* $\mathrm{XX} \quad \mathrm{x} \underline{\mathrm{X}}\{\mathrm{x}\}+\mathrm{X}$ o Xx $\mathrm{X} \mathrm{x} \underline{\mathrm{X}}\{\mathrm{x}\}(4+6)$

The third scansion shows a divided line with internal extrametricality. Examples (21) and (22) above might be similarly divided; the addition of (24) makes three lines out of 2376 in Laberinto. However, with different variants we can arrive at a correct unified version of this line too; this is only one of the existing possibilities: "de los passa\#dos, si quiés ver espan\{to\}" (4\#6).

The following line is equally problematic, now due to the fact that the initial colon is perhaps realized by three syllables and to the relative length of the cola:

(25) ${ }^{\star}$ Femonoe, por orden la sesta (1. 969)

$$
\begin{array}{llllllll}
\mathrm{x} & \mathrm{x} & \underline{X} \# \mathrm{x} & \mathrm{x} & \mathrm{X} & \mathrm{x} & \mathrm{x} & \underline{\mathrm{X}}\{\mathrm{x}\}(3 \# 6) \\
\mathrm{x} & \mathrm{x} & \underline{X} \mathrm{X} \# & \mathrm{x} & \mathrm{X} & \mathrm{x} & \mathrm{x} & \underline{X}\{\mathrm{x}\}(3 \# 5) \\
\mathrm{x} & \mathrm{x} & \mathrm{Xx} & \mathrm{x} & \underline{\mathrm{X}} \# \mathrm{x} & \mathrm{x} & \underline{\mathrm{X}}\{\mathrm{x}\}(6 \# 3) \\
\mathrm{x} & \mathrm{x} & \mathrm{Xo} & \mathrm{x} & \underline{X} \# \mathrm{x} & \mathrm{x} & \underline{\mathrm{X}}\{\mathrm{x}\}(5 \# 3)
\end{array}
$$

With other variants the line would read, for example, "Femona por or\#den era la ses\{ta\}" (5\#5), whose correctness is beyond dispute.

This line is divided or else ends in a 7-syllable colon:

(26) *de los que demuestran y de los demostrados (1. 1028)

$$
\begin{aligned}
& \ldots+\{x\} \quad X \quad X X \quad x \quad x \quad \underline{X}\{x\}
\end{aligned}
$$

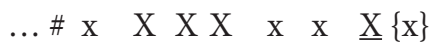

Some manuscripts read "de los que demues\#tran e los demostra\{dos\}", with a correct 6-syllable colon at the end.

In the following case, the final colon remains correct, in terms of length, only if the two vowels separated by the letter $h$ are treated as one (which proves that this letter is no obstacle to doing so):

(27) que fe non se guarden hermanos a hermanos (1. 2031)

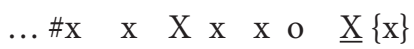


Though Piera's amphibrachic account does not find any incorrect lines in Laberinto (1981: 144), one of the lines that I find problematic - example (22) is also considered incorrect in Piera's second account (2008: 125). Other lines that he deems incorrect can be considered well-formed examples of the $5 \# 6$ type: line 791 ("que de lo gana\#do sufre mengua $\tan \{\operatorname{ta\} }$ ", scanned as X X X X $\underline{\mathrm{X}} \# \mathrm{x} \mathrm{X} \times \mathrm{X}$ o $\mathrm{x} \underline{\mathrm{X}}\{\mathrm{x}\}$ ) and line 354 ("de parte del Aus\#tro vimos toda Gre $\{$ cia\}", scanned as $\mathrm{x} X \times \mathrm{x} \underline{\mathrm{X}} \mathrm{o} \# \mathrm{x} \mathrm{X} \times \mathrm{X} \times \underline{\mathrm{X}}\{? \mathrm{x}\}$, where the ? mark indicates that the metrical status of a vowel is unclear).

As regards the constructs that Piera presents as possibly correct (Piera 2008: 123), one is obviously incorrect by my rules:

(f) *do veredes los grandes señores e los reyes (based on 1. 1779)

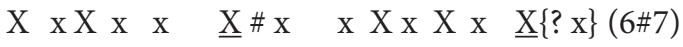

$$
\begin{aligned}
& \mathrm{X} \times \mathrm{X} \times \mathrm{x} \quad \underline{\mathrm{X}}\{\mathrm{x}\}+\mathrm{x} X \times \mathrm{X} \times \underline{\mathrm{X}}\{? \mathrm{x}\}(6+6)
\end{aligned}
$$

Another construct that Piera provisionally allows I find incorrect, at least if we accept his disyllabic interpretation of the first word (by virtue of which the line begins with a 3-syllable colon):

(g) vieras otro d’essa nación (based on 1. 558)

${ }_{\mathrm{O}} \mathrm{OXx} \quad \underline{\mathrm{X}} \# \mathrm{x} \ldots$

This line is correct if we treat vieras as a trisyllable; with the scansion $\mathrm{x} \mathrm{X} \times \underline{\mathrm{X}}$ \# the line is of the $4 \# 5$ or $4 \# 6$ type.

In this other construct that Piera judges problematic but possibly correct, it is the final colon that causes difficulties:

(h) oras silvando tanto drago (based on 1. 1965, quoted as example (10') above) $\mathrm{Xx} \quad \mathrm{x} \underline{\mathrm{X}} \# \mathrm{x} X \quad \mathrm{x} \quad \underline{\mathrm{X}}\{\mathrm{x}\}$

This example belongs to the $4 \# 4$ type, which is incorrect only if we take arte mayor - qua long unified dolnik with four strong positions - to exclude the 4-syllable realization of the final colon. It is precisely to this and other related issues that I turn now. 


\section{Other constant but not necessary characteristics of Laberinto}

One major problem with the dolnik account of arte mayor offered so far is that in Laberinto all final cola are realized by at least five syllables. The absence of final cola featuring four syllables means that Mena shunned 8-syllable lines. This peculiarity lends weight to the amphibrachic hypothesis. In Piera's version of it (1981), 1-syllable extrametricality is acceptable at the beginning of lines; both cola can be headless, and the line can be truncated; between the syllables realizing two strong positions within the same colon there are always two syllables. The corresponding template can be represented as:

$\{\mathrm{w}\}(\mathrm{w}) \mathrm{s} \mathrm{w} \mid \mathrm{w}$ s w \# (w) s w $\mid$ w s $(\mathrm{w})^{27}$

One possible charge against the amphibrachic account is that 4-syllable final cola (with one syllable alone between the syllables realizing the strong positions), and hence 8-syllable lines, do appear in other authors' arte mayor.

In his first approach to Laberinto, Piera notes that some nonamphibrachic "descriptions predict eight-syllable lines, whose conspicuous absence from all major poems must then be explained away" (Piera 1981: 102). Even if in Mena's composition final cola are always realized by five or more syllables, this constant characteristic may not be necessary for other kinds of arte mayor. The best way to determine whether arte mayor admits of $4 \# 4$ lines is to find them in compositions using what appears to be the same metre. Actually, this line type is not unheard of. This is an instance by Imperial (Dutton, González Cuenca eds. 1993: 261):

(28) Tan grant amor nunca mostraron $\begin{array}{llllllll}\mathrm{X} & \mathrm{X} & \mathrm{X} & \underline{\mathrm{X}} & \# \mathrm{X} & \mathrm{x} & \mathrm{X} & \underline{\mathrm{X}}\{\mathrm{x}\}^{28}\end{array}$

\footnotetext{
27 According to Duffell (1999: 68), the third foot cannot be headless, while the second can be truncated: $\{\mathrm{w}\}$ (w) s w| w s (w) \# w s w|w s (w).

28 The initial colon is oxytonic, and, despite all appearances, the internal weak position of the final colon cannot be filled by two syllables, as this would mean positing two consecutive strong positions (one at the end of the initial colon and another at the beginning of the final one, as in some divided lines). The paroxytonic disyllable nunca contains a maximum followed by a nonmaximum realizing a strong position, both within the same foot; in this respect, this line is similar to several others of Laberinto already mentioned: 1. 284, scanned as example (13); 1. 232, example (14').
} 
In addition to Imperial, there are other authors that accept 8-syllable lines. A case in point is the 20th-century writer Valle-Inclán, arguably one of a handful of versifiers that kept the Spanish arte mayor tradition alive. In his "Los pobres de Dios" = "God's Poor" (Valle-Inclán 1995: 67), written in what seems to be an 8-position dolnik, we find $5 \# 6$ and $4 \# 5$ lines with a strong resemblance to those of in Laberinto:

(29) Va la caravana de los desvalidos $\mathrm{XX} \quad \mathrm{x} \times \underline{\mathrm{X}} \# \mathrm{X} \quad \mathrm{X} X \quad \mathrm{X} \quad \mathrm{x} \underline{\mathrm{X}}\{\mathrm{x}\}$

(30) El polvo quema sus llagas rojas $\begin{array}{llllllll}\mathrm{x} & \mathrm{X} & \mathrm{x} & \underline{X} \# \mathrm{X} & \mathrm{x} & \mathrm{X} & \mathrm{x} & \underline{X}\{\mathrm{x}\}\end{array}$

However, there are also $4 \# 4$ lines:

(31) Por los caminos florecidos $\mathrm{X} \quad \mathrm{X} \quad \mathrm{x} \quad \underline{\mathrm{X}} \# \mathrm{x} \quad \mathrm{x} x \underline{\mathrm{X}}\{\mathrm{x}\}$

(32) En donde cantan las vaqueras $\begin{array}{lllllll}\mathrm{X} & \mathrm{X} & \mathrm{x} & \underline{\mathrm{X}} \# \mathrm{X} & \mathrm{X} & \mathrm{x} & \underline{\mathrm{X}}\{\mathrm{x}\}\end{array}$

All four examples, like the other lines in the composition from which they are taken, display the word boundary between cola mentioned in connection with Laberinto. Indeed, this is one of the reasons to conclude that Valle-Inclán "Los pobres de Dios" is, like Mena's work, an example of arte mayor. Therefore Piera's construct (h), scanned above, can be tentatively labelled as a correct 4 \#4 line. ${ }^{29}$

29 Apart from a dubious case with contiguous vowels like "a Rute e Prie\#go e a Carcabuey" (l. 2036), which can be scanned in several other ways (e.g. as 4\#5), the $4 \# 4$ line type is absent from Laberinto. By contrast, Mena uses $6 \# 6$ lines, which are avoided by Valle-Inclán. It could be hypothesized that, while Mena wants to keep its distance from popular arte menor by avoiding initial cola of three syllables and final cola of four (cf. Piera 2008: 123), Valle-Inclán does aim at a popular flavour. In this regard, we cannot forget that Valle-Inclán was of Galician origin, and that "Los pobres de Dios" is closed by a stanza made up of four isosyllabic 7-position lines (romance), borrowed from a well-known folk song in the Galician-Portuguese language. Among the possible origins of arte mayor, the influence of Galician-Portuguese versification on mediaeval Spanish verse has been mentioned since Santillana's Proemio = Preface (Santillana 2003: 653). This explanation has been accepted by many modern scholars (e.g. Le Gentil 1953: 409; Clarke 1964: 53, 219; Lázaro Carreter 1972: 344-345; Navarro Tomás 1974: 121-122; Gasparov 1996: 138; García Calvo 2006: 1650-1651; Domínguez Caparrós 2014: 166). While Spanish 
If final cola realized by four syllables are accepted, then arte mayor is less likely to be an amphibrachic form than a dolnik. Further confirmation of this view would come in the form of headless lines with initial cola realized by three syllables (corresponding to the metrical sequence s w s \#). Because of the presence of contiguous vowels, on the one hand, and of the existence of manuscript variants, on the other, there are no certain instances of this phenomenon in Laberinto; ${ }^{30}$ but two possible cases can be found in "Son de muñeira" = "The Sound of the Mill-Song", another composition by Valle-Inclán (1995: 89). ${ }^{31}$ In my scansion I have assumed that contiguous vowels in the final colon do not count:

$$
\begin{aligned}
& \text { ¡Toc! ¡Toc! ¡Toc!... Bate la espadela } \\
& \mathrm{X} \quad \mathrm{X} \quad \underline{\mathrm{X}} \# \quad \mathrm{X} \mathrm{xX} \text { o } \quad \underline{\mathrm{X}}\{\mathrm{x}\} \text { (3\#5) } \\
& \text { (34) ¡Toc! ¡Toc! ¡Toc!... Da vueltas la muela } \\
& \mathrm{X} \quad \mathrm{X} \quad \underline{\mathrm{X}} \quad \# \quad \mathrm{X} \quad \mathrm{oX} \mathrm{x} \quad \mathrm{x} \quad \mathrm{o} \underline{\mathrm{X}}\{\mathrm{x}\}(3 \# 5)
\end{aligned}
$$

The truth, however, is that both lines can be scanned differently: the initial cola can be continued up to the fourth maximum, and there is the possibility of counting a greater number of contiguous vowels. For this reason, I provisionally dismiss initial cola with fewer than four syllables, here and in Laberinto.

As regards extrametricality at the end of lines, in Laberinto it is always limited to one syllable. However, in Spanish this limitation is not usually

arte mayor was abandoned when the Italianate 10-position line was introduced for learned verse, in Galician-Portuguese it remained (under the name of verso de moinheira = mill-song verse) a central form both in the oral tradition and in the written tradition of folk inspiration, as evidenced by the work of the 19th-century Galician writer Rosalia de Castro. In the hands of Galician authors, even of those writing in Spanish, verso de moinheira has never been constrained by the learned connotations that arte mayor had acquired in mediaeval Spanish, and thus remained free from some of the stylistic limitations that Mena imposed on his Laberinto. Despite their different minimum and maximum line lengths, the identity between the verso de moinheira and arte mayor has been affirmed by Henríquez Ureña (2003: 205-207). Proof that the absence of certain line types does not necessarily point to a different metre comes from Santillana's "Comedieta de Ponça" = "Little Comedy of Ponça" (Santillana 2003: 295-356), whose verse is clearly the same as Mena's - $5 \# 6$ lines predominate, appearing side by side with a few $4 \# 5,4 \# 6$ and $6 \# 6$ lines - despite lacking $5 \# 5$ lines without contiguous vowels.

30 To be sure, a Laberinto line like "O virtuo\#sa, magnífica gue\{rra\}" (1. 2019) can be scanned as $3 \# 6$, but also as $4 \# 6$ (the latter is the option preferred by editors, who indicate this reading by means of diaeresis: virtüoso $=$ virtuous).

31 Despite its title, Valle-Inclán's composition was not for singing but for recitation. 
considered to distinguish among verse types (which are generally allowed to mix oxytonic, paroxytonic and proparoxytonic endings), so we cannot be certain that this is a necessary requirement for all arte mayor. After all, the insertion of two extrametrical syllables at line end is a permissible variation in authors other than Mena. Witness this example by Villasandino (Dutton, González Cuenca eds. 1993: 162):

(35) Filósofo firme e grant metafísico

[...]

non entendades que só tan çentífico

Like other lines in the same composition (analysed as arte mayor in Saavedra Molina 1945: 116, and Piera 1981: 132), these two have the ending $\underline{X}\{\mathrm{x} \mathrm{x}\}$, absent from Laberinto but included among the accepted elements of arte mayor by such scholars as Foulché-Delbosc (1902: 102-103), Navarro Tomás (1974: 115-116) and Saavedra Molina (1945: 27, 30). Despite its exclusion from Mena's composition, double extrametricality can be provisionally permitted as an option in arte mayor (cf. Piera 1981: 100, 131-134). ${ }^{32}$

After this comparison between Laberinto and works by other authors, it appears that the necessary characteristics of arte mayor may be fewer than those that are constant in Mena's composition. In this light, the latter comes over as a relatively strict version of the metre. ${ }^{33}$

\footnotetext{
32 Further doubts about the demand to avoid double extrametricality in arte mayor are cast by an isosyllabic 10-position line like "que tienen fama en este mundo va\{rio\}", by the late-16thcentury writer Bartolomé Carrasco de Figueroa. In the composition to which it belongs, it appears surrounded by proparoxytonic lines alone, and is therefore supposed to have two extrametrical syllables rather than one (cf. Alatorre 2007: 194). Theoretically, the same interpretation could be given to similar endings with contiguous vowels in Laberinto, such as "privados de to\#da visiva poten\{çia\}" (l. 148, of the $5 \# 6$ type).

33 If we compare the constant characteristics of the Laberinto verse with Tarlinskaja's description of the English dolnik, a couple of interesting differences emerge. Tarlinskaja speaks of void weak positions, most often the first one, but also internally (cf. Tarlinskaja 1993: 12-13); but in Laberinto all internal weak positions are realized by at least one syllable. The other difference is that the only constant feature that she contemplates in the realization of the metre is that the internal stresses of polysyllables are avoided in weak positions (the distribution of other stresses and nonstresses is fairly predictable, but always with exceptions), while in Laberinto the constant feature is that colon-final strong positions are always realized by maxima.
} 


\section{Possible characteristics of other arte mayor}

The use of final 4-syllable cola might not be Imperial's only departure from the arte mayor standard subsequently set by Mena. Imperial also has initial 3-syllable cola and final 7-syllable cola, and in some of his lines the initial colon is the longer. These phenomena indicate that his metrical rules might be looser than those followed by Mena and by other authors (Dutton, González Cuenca eds. 1993: 312): Imperial might have admitted both headless lines with 3-syllable cola (e.g. "son donze\#llas de grant exçelen\{çia\}, a line of the $3 \# 6$ type) and the interspersion of lines divided by epic caesura (e.g. "la quinta lla\{man\} + Conjurado Sermón", of the $4+6$ type); also, he might have combined his cola quite freely (e.g. "e vence voluntat \# desenfrena\{da\}", of the $6 \# 4$ type). ${ }^{34}$ By these rules - which may still result in arte mayor, but which certainly do not coincide with those of its mainstream variety, i.e. of arte mayor qua long unified dolnik with four strong positions, let alone with those of the stricter mainstream represented by Laberinto - all of the lines interpreted as incorrect in the preceding sections would become automatically correct.

\section{Conclusion}

The anisosyllabic metre of Mena's Laberinto has often been considered the most perfect example of Spanish arte mayor. I have analysed the verse employed by Mena - and by other authors, from the Middle Ages to the 20th-century - as a kind of syllable-stress dolnik with a predominant ternary rhythm.

My claim that arte mayor is a syllable-stress form is based on the following considerations. If a metre that only regulates syllables (or metrical elements based on syllables) is syllabic, and a metre that only regulates stresses (or metrical elements based on stress) is accentual, then it is reasonable to interpret as syllabic-accentual any metre that regulates (metrified) syllables and (metrified) stresses in some way. Crucially, Spanish metres usually regulate both the syllable count and the minimal number and placement of stresses along the line: all colon- and line-final strong positions must be realized by stresses. The latter rule applies to the immense majority of Spanish metres; so much so that traditional Spanish metrists impose it even on places where it does not

\footnotetext{
34 Some of Imperial's lines are ambiguous; e.g. "La del semblan $\{$ te $\}+$ nin alegre nin tris $\{$ te $\}$ " (of the $4+6$ type), which can also be interpreted as "La del semblante nin \# alegre nin tris\{te\}" (of the $6 \# 5$ type).
} 
apply (hence their prescription of stress wrenching in the middle of cola and lines). In relation to Spanish, then, Duffell is eminently correct when he says that, in general, "The patterns of Romance [... metrical] verse are based on two linguistic features, syllable count and accentuation. No Romance verse is purely syllabic", as the "metres contain mandatory positions for accented syllables" (1996: 211).

From the perspective of metrical traditions where stresses are regulated in a different way, it might seem that Spanish metres are too irregular, as certain stretches within the lines seem to follow no discernible organization; but the fact remains that they are as strictly (even if differently) regulated as many others - e.g. English ones, whose general syllable-stress character no one seriously denies. In this respect, one could say that Spanish metres simply obey the rule that correspondence to metrical template tends to be lax at the beginnings of units and strict at the ends (cf. Hayes 1983: 373). In Spanish metres, these (colon- and line-) ends can be placed quite far apart (e.g. in strict a minore 10-position lines in which only the 4 th and 10th positions are always filled by a stress, while other stresses, despite following certain statistical tendencies, are optional), or as close together as every four syllables (e.g. in strict 7-position lines in which the 3 th and 7 th positions must be filled by a stress, while other stresses are optional). At most we could say that in the stretches preceding those ends, Spanish metres may display syllabic tendencies (though in many metres stresses are statistically regulated even at the beginning of cola and lines). But, in general, the issue is qualitative rather than quantitative: in a language like Spanish in which stress is not fixed or always predictable, it is not really possible to tell the length of a metrical line just by counting the (metrified) syllables. At least one (metrified) stress must be taken into account. Take a simple case in point: a 7-syllable line can realize a 7-position template without final extrametricality (if the line ends ...X), a 6-position template (if the line ends ...X $\{\mathrm{x}\}$ ), a 5-position template (if the line ends ...X $\{\mathrm{x} x\})$, a 4-position template (e.g. the construct "adelantán\{dosenos\}": $\mathrm{x} \times \mathrm{x}$ $\mathrm{X}\{\mathrm{x} \times \mathrm{x}\}$ ), and, theoretically, even a 3-position template (e.g. the construct "acabán\{dosetelos\}": $\mathrm{x} \times \mathrm{X}\{\mathrm{x} \times \mathrm{x} \times \mathrm{x}\}$ ). If verse like this cannot be identified without paying attention to syllables and stresses, then it surely belongs to the syllable-stress kind.

As regards the dolnik hypothesis, it consists in assuming strong positions to be realized by one syllable and separated by another two or one from the syllable realizing the nearest strong position. Arguing that the realization rules of Mena's arte mayor do not count prosodic syllables proper but metrically relevant segments (metrified syllables) and that they do not regulate directly the distribution of stresses and nonstresses but of (usually stressed) maxima 
and (unstressed) nonmaxima (metrified stresses and nonstresses), this article begun by analysing the constant and necessary characteristics of the verse of Laberinto: two rising cola, each with two strong positions; extrametricality aside, each colon is realized by four to six syllables; as in other dolnik, every strong position is realized by one syllable and every internal weak position by one or two; colon-final strong positions must be realized by maxima, whether stressed or not; both cola are kept distinct by a midline boundary rule, such that the syllables realizing the last strong position of the initial colon and the first strong position of the final colon cannot belong to the same syntactic word, in spite of which the lines can be said to be unified; unusually for Spanish metres, headlessness is permitted (but only as long as the initial colon is realized by at least four syllables); the final colon cannot be shorter than the initial one, so it must be realized by at least five syllables; extrametricality only appears at line end, and it is confined to one nonmaximum, so proparoxytonic line ends and extrametrical atonic words are not tolerated.

I have tried to explain as many arte mayor features as possible - some admittedly rare, though shared by other Spanish metres - as correct and as necessary. Hence, to begin with, the attempt to explain the arte mayor of Laberinto as a dolnik rather than as a ternary metre allowing headlessness, a decision intended to accommodate lines whose final colon is realized by five syllables instead of six, and, in addition, the substitution of stress maxima for stresses, a move designed to account for line-end atonic words. It is clear, however, that the metre of Laberinto, like other Spanish metres, regulates the line length - whose variation it keeps within precise limits - and the placement of maxima at colon and line end more strictly than the placement of other maxima elsewhere in the line. As a result, between maxima - as against the syllables realizing strong positions - there can be less than one or more than two syllables. If it can be stated that - to make room for all the vocabulary in the language and to avoid monotony - syllable-stress dolnik in English can display accentual tendencies, when weak positions are left unrealized (Tarlinskaja 1993: 13, 199; Duffell 2008: 34; Attridge 2013: 107-108, 155 n. 11), so, conversely, it is tempting to suggest that Spanish dolnik tends towards syllabism, when the distribution of maxima and nonmaxima does not reveal but obscures (outside colon and line ends) the distribution of strong and weak positions; but, given its strong preference for a ternary rhythm, it can be concluded that Laberinto is not characterized by such syllabic tendencies.

In relation to rhythm, it is clear that in Spanish 1- and 2-syllable intervals cannot be the only defining characteristic of dolnik proper: one can write verse with a rhythm that mixes iambs and anapaests while sticking to isosyllabism (e.g. romance, a strict sequence of 7-position lines in which each position 
amounts to one syllable, and in which it does not usually matter if the rhythm of some lines is binary, of some ternary and of others mixed). Some authors have spoken of dolnik when dealing with Spanish compositions made up of isosyllabic lines displaying mixed rhythms only (e.g. Gasparov 1996: 136). To be sure, this can be done when it can be demonstrated that such lines evolve from anisosyllabic dolnik, but this latter, original variety should never be forgotten.

Not all the constant features of Laberinto are necessary in other kinds of arte mayor. As it turns out, Mena's verse is a singularly strict variety of mainstream arte mayor (defined as long unified dolnik with four strong positions). In other mainstream arte mayor, the final colon can be realized by four syllables (though still not shorter than the initial one), and the line end can be proparoxytonic. Lines with these characteristics do not appear in Mena's work, or else they are so scarce as to be better viewed as incorrect; but if they appeared, or if they were more frequent, it would not be reasonable to say that they result in a substantially different metre.

I have provisionally argued for the existence of yet other kinds of arte mayor. These seem to have only two necessary characteristics: four strong positions (the second and fourth colon-final and corresponding to maxima) and a midline boundary between syntactic words. The possibilities accepted here but not in mainstream arte mayor would be: headlessness combined with initial cola of fewer than four syllables, and the existence of a looser variety and of two stricter varieties. In the loosest version arte mayor becomes a taktovik and/ or a divided 2-hemistich line (with internal extrametricality, i.e. epic caesura), and it allows a final colon that is shorter than the initial one. ${ }^{35}$ As regards the versions that are stricter than the mainstream, one amounts to a ternary metre whose final colon is always realized by six syllables, the permitted combinations of lines types being thus limited to $4 \# 6,5 \# 6$ and $6 \# 6$; the strictest version of arte mayor is not only rigorously ternary but isosyllabic: all lines are of the $4 \# 6$ or $5 \# 6$ or $6 \# 6$ type. $^{36}$

In order to achieve a full understanding of the rhythmic range of arte mayor (cf. Duffell 1999: 73-74), it is necessary to perform a complete statistical analysis of its variable characteristics, beginning with the ternary or binary movement that predominates (the latter is the norm, for example, in ValleInclán's "Los pobres de Dios"). While studying the characteristics of all the

35 It would be logical to expect initial cola falling short of four syllables and the interchangeability of cola in certain varieties, other than Mena's, of mainstream arte mayor; however, this does not seem be the case (the reasons need studying).

36 For example, Santillana's composition beginning "Robadas havían el Austro e Borea" apparently consists of 5\#6 lines alone (Santillana 2003: 285-294). 
forms of Spanish arte mayor that might exist, it is nevertheless important to remember Clarke's claim that there have been as many varieties of this verse as there are practitioners of it, and that "the rule" was "that each poet was a law unto himself in the matter of rhythm interpretation" (1964: 210). It might well be that arte mayor is less a single metre than a cluster of different forms with some family resemblance (cf. Clarke 1964: 92). Thus, it must be borne in mind that "arte mayor from the beginning enjoyed a loose form along with the restricted, which later gradually took precedence over its rival", leading to "the monotony of rigid pattern" $(60,50)$. While some arte mayor texts seem to be genuine dolnik, others might be best described as strict ternary verse and even - e.g. when the placement of the colon boundary is rigorously fixed - as effectively amphibrachic; still others might eventually be identified as taktovik. This would mean applying Piera's second account of arte mayor, if not to Laberinto, as he did, then to other texts; more generally, this would lead to accept the existence in Spanish, and therefore in Romance languages, of the taktovik form hitherto proved to exist only in languages like Russian, English and Latvian (cf. Gasparov 1996; Fabb, Halle 2008). ${ }^{37}$ As a result, the necessary characteristics of arte mayor might be reduced in number or even declared nonexistent, at which point the very label arte mayor, whatever its convenience as an umbrella term, would lose much of its analytic usefulness.

Meanwhile, the results obtained here warrant the provisional conclusion that the dolnik form has been cultivated not only in Slavic, Baltic and Germanic languages, from Russian to English, but also in a Romance language like Spanish. In this respect, it cannot be forgotten that, before the emergence of arte mayor, a number of similar forms had already been cultivated in other Romance languages from Galician-Portuguese to Italian (cf. Burger 1957:

37 Some authors - of whom Geers was perhaps the first (Geers 1930: 179-18; cf. Morley 1933: 968), but certainly not the last (e.g. Pellen 1985: 10; Orduna 1987: 10-11, 23; García Calvo 2006: 1617-1623) - have characterized the rhymed verse of the Spanish epic Cantar de Mio Cid= Song of My Cid (composed c.1200) as a long, two-part metre with four strong positions; in the nomenclature used here, it would correspond to either taktovik or loose anapaest. (Succinct descriptions of the form can be found in Gasparov 1996: 134-135; Domínguez Caparrós 2014: 159-161.) The problem is that the text of the only extant manuscript does not seem to bear out these characterizations (even their proponents sometimes recognize the existence of many lines with the "wrong" number of stresses and/or syllables). This is perhaps because, as some argue (e.g. Fernández, Brío 2004), the work was meant to be performed to the accompaniment of (now lost) music. To solve these difficulties, other authors have suggested more strong positions: as many as six (though he speaks of "stresses", this seems to be the view favoured by Smith 1979: 52) or even eight (speaking of "beats", Leonard 1931: 293). From today's perspective, the Cid reads much like rhymed free verse. 
40-43). And, just like arte mayor has coexisted with other Spanish metres that look much like its short counterparts, ${ }^{38}$ future research may uncover other Romance traditions in which dolnik metres are similarly varied. A complete comparative analysis of these forms, on the linguistic basis argued for here, is still pending.

\section{References}

Alatorre, Antonio 2007. Cuatro ensayos sobre arte poética. México D.F.: El Colegio de México.

Attridge, Derek 1982. The Rhythms of English Poetry. London: Longman.

Attridge, Derek 2012. The case for the English dolnik; or, how not to introduce prosody. In: Poetics Today 33(1), 1-26. https://doi.org/10.1215/03335372-1505522

Attridge, Derek 2013. Moving Words: Forms of English Poetry. Oxford: Oxford University Press.

Balaguer, Joaquín 1995. Apuntes para una historia prosódica de la métrica castellana. Santo Domingo: Editora Corripio.

Bello, Andrés 1884. Principios de la ortolojía i métrica de la lengua castellana. In: Consejo de Instrucción Pública (ed.), Obras completas de don Andrés Bello 5: Opúsculos gramaticales. Santiago de Chile: Pedro G. Ramírez, 3-229.

Burger, Michel 1957. Recherches sur la structure et l'origine des vers romans. Genève: Droz.

Chisholm, David 1995. Prosodic aspects of German hexameter verse. In: Poetics Today 16(3), 523-545. https://doi.org/10.2307/1773177

Clarke, Dorothy Clotelle 1964. Morphology of Fifteenth-Century Castilian Verse. Pittsburgh: Duquesne University Press.

Correas, Gonzalo 1954. Arte de la lengua española castellana. Madrid: CSIC.

Díaz Rengifo, Juan 2012. Arte poética española. Kassel: Edition Reichenberger.

38 Let us just recall such anisosyllabic forms as the verso de seguidilla, with between four and six syllables up to the rightmost (metrified) stress, and the verso semilibre menor, with between three and six syllables (for the former, cf. Navarro Tomás 1974: 177-182, 240-241, 292-293, 340; for the latter, cf. Navarro Tomás 1974: 524). Both can be argued to be underlain by the template w s w s $\{\mathrm{x}\}$, without and with optional headlessness, respectively. 
D’Introno, Francesco; Teso, Enrique del; Weston, Rosemary 1995. Fonética y fonología actual del español. Madrid: Cátedra.

Domínguez Caparrós, José 2014. Métrica española. 3rd rev. ed. Madrid. UNED.

Duffell, Martin J. 1996. Chaucer, Gower, and the History of the Hendecasyllable. In: McCully, Christopher B.; Anderson, John J. (eds), English Historical Metrics. Cambridge: Cambridge University Press, 210-218.

Duffell, Martin J. 1999. Modern Metrical Theory and the Verso de Arte Mayor. London: Department of Hispanic Studies, Queen Mary and Westfield College, University of London.

Duffell, Martin J. 2008. Triple time in English verse. In: Rhythmica: Revista Española de Métrica Comparada 5-6, 23-48.

Dutton, Brian; González Cuenca, Joaquín (eds.) 1993. Cancionero de Juan Alfonso de Baena. Madrid: Visor.

Fabb, Nigel; Halle, Morris 2008. Meter in Poetry: A New Theory. Cambridge: Cambridge University Press.

Fernández, Guillermo; Brío, Clara del 2004. Sobre la métrica del Cantar de Mio Cid. Música y épica: La cantilación de las gestas. In: Lemir 8, 1-37.

Foulché-Delbosc, Raymond 1902. Étude sur le Laberinto de Juan de Mena. In: Revue hispanique: Recueil consacré à l'étude des langues, des littératures et de l'histoire des pays castillans, catalans, et portugais 9(29), 75-138.

García Calvo, Agustín 2006. Tratado de rítmica y prosodia y de métrica y versificación. Zamora: Lucina.

Gasparov, Mikhail L. 1996. A History of European Versification. Oxford: Oxford University Press.

Geers, Gerardus Johannes 1930. Algo sobre versificación española. In: Neophilologus 15, 178-183. https://doi.org/10.1007/BF01510199

Góngora, Luis de 1985. Sonetos completos. Madrid: Castalia.

Halle, Morris; Keyser, Samuel Jay 1966. Chaucer and the study of prosody. In: College English 28(3), 187-219. https://doi.org/10.2307/374038

Halle, Morris; Keyser, Samuel Jay 1971. Illustration and defense of a theory of the iambic pentameter. In: College English 33(2), 154-176. https://doi.org/10.2307/374744

Hanson, Kristin 2008. Review of Fabb, Nigel; Halle, Morris 2008. In: Language 84(2), 370-386. https://doi.org/10.1353/lan.0.0026 
Harris, James W. 1983. Syllable Structure and Stress in Spanish: A Non-Linear Analysis. Cambridge and London: MIT Press.

Hayes, Bruce 1983. A grid-based theory of English meter. In: Linguistic Inquiry 14(3), 357-393.

Henríquez Ureña, Pedro 2003. Estudios de versificación española. In: Obras completas 3: Estudios métricos. Santo Domingo: Secretaría de Estado de Cultura, Editora nacional, $163-440$.

Hualde, José Ignacio 2009. Unstressed words in Spanish. In: Language Sciences 31(2/3), 199-212. https://doi.org/10.1016/j.langsci.2008.12.003

Hualde, José Ignacio 2010. Secondary stress and stress clash in Spanish. In: OrtegaLlebaria, Marta (ed.), Selected Proceedings of the 4th Conference on Laboratory Approaches to Spanish Phonology. Somerville: Cascadilla Proceedings Project, 11-19.

Hualde, José Ignacio 2014. Los sonidos del español. Cambridge: Cambridge University Press.

Hualde, José Ignacio; Nadeu, Marianna 2014. Rhetorical stress in Spanish. In: Hulst, Harry van der (ed.), Word Stress: Theoretical and Typological Issues. Cambridge and New York: Cambridge University Press, 228-252.

Jakobson, Roman 1966. Linguistics and poetics. In: Sebeok, Thomas A. (ed.), Style in Language. Cambridge: MIT Press, 350-377.

Ker, William Paton 1899. Analogies between English and Spanish verse (arte mayor). In: Transactions of the Philological Society 24(1), 113-128.

https://doi.org/10.1111/j.1467-968X.1899.tb00138.x

Kiparsky, Paul 1977. The rhythmic structure of English verse. In: Linguistic Inquiry 8, 189-247.

Lázaro Carreter, Fernando 1972. La poética del arte mayor castellano. In: Studia Hispanica in Honorem R. Lapesa 1. Madrid: Gredos, 343-378.

Le Gentil, Pierre 1953. La poésie lyrique espagnole et portugaise à la fin du moyen âge 2. Rennes: Plihon.

León, Luis de 2011. Poesía. 13th ed. Madrid: Cátedra.

Leonard, William Ellery 1931. The Recovery of the Metre of the Cid. In: PMLA 46(2), 289-306. https://doi.org/10.2307/458034

Mena, Juan de 1979. Laberinto de fortuna. Madrid: Cátedra.

Mena, Juan de 1995. Laberinto de fortuna. Madrid: Castalia. 
Morales-Front, Alfonso 2014. El acento. In: Núñez Cedeño, Rafael; Colina, Sonia; Bradley, Travis G. (eds.), Fonología generativa contemporánea de la lengua española, 2nd rev. ed. Washington, D.C.: Georgetown University Press, 235-265.

Morel-Fatio, Alfred 1894. L'arte mayor et l'hendécasyllabe dans la poésie castillane du XVe siècle et du commencement du XVIe siècle. In: Romania 23(90), 209-231. https://doi.org/10.3406/roma.1894.5820

Morley, S. Griswold. 1933. Recent theories about the meter of the Cid. In: PMLA 48(4), 965-980. https://doi.org/10.2307/458191

Navarro Tomás, Tomás 1967. Manual de pronunciación española. 6th ed. New York and London: Hafner.

Navarro Tomás, Tomás 1974. Métrica española: Reseña histórica y descriptiva. 4th ed. Barcelona: Labor.

Nebrija, Antonio de 2011. Gramática sobre la lengua castellana. Barcelona: RAE; Galaxia Gutenberg.

Nespor, Marina; Vogel, Irene 1989. On clashes and lapses. In: Phonology 6(1), 69-116. https://doi.org/10.1017/S0952675700000956

Orduna, Germán 1987. Función expresiva de la tirada y de la estructura fónico-rítmica del verso en la creación del Poema de Mio Cid. In: Incipit 7, 7-34.

Pellen, René 1985. Le modèle du vers épique espagnol, à partir de la formule cidienne "El que en buen hora..." (Exploitation des concordances pour l'analyse des structures textuelles). In: Cahiers d'Études Hispaniques Médiévales 10(1), 5-37. https://doi.org/10.3406/cehm.1985.948

Piera, Carlos 1981. Spanish Verse and the Theory of Meter [unpublished PhD thesis]. Los Angeles: UCLA.

Piera, Carlos 2003a. Del verso español y los universales métricos. In: Mairal, Ricardo; Gil; Juana (eds.), En torno a los universales lingüísticos. Madrid: Cambridge University Press; Akal, 265-303.

Piera, Carlos 2003b. Intonational factors in metrics. In: Michaux, Christine; Dominicy, Marc (eds.), Linguistic Approaches to Poetry. Amsterdam: John Benjamins, 206-228.

Piera, Carlos 2008. Southern Romance. In: Fabb, Nigel; Halle, Morris Meter in Poetry: A New Theory. Cambridge: Cambridge University Press, 94-132.

Quilis, Antonio 1993. Tratado de fonología y fonética española. Madrid: Gredos.

RAE [Real Academia Española] 2011. Nueva gramática de la lengua española 3: Fonética y fonología. Madrid: Espasa. 
Roca, Iggy M. 1986. Secondary stress and metrical rhythm. In: Phonology Yearbook 3, 341-370. https://doi.org/10.1017/S0952675700000683

Rodríguez Vázquez, Rosalía 2010. The Rhythm of Speech, Verse and Vocal Music: A New Theory. Bern: Peter Lang.

Roubaud, Jacques 1971. Mètre et vers: deux applications de la métrique générative de Halle-Keyser. In: Poétique 7, 366-387.

Saavedra Molina, Julio 1945. El verso de arte mayor. In: Anales de La Universidad de Chile 57-58, 5-127.

Salinas, Francisco de 1983. Siete libros sobre la música. Madrid: Alpuerto.

Santillana, Marquis of 2003. Poesías completas. Madrid: Castalia.

Smith, Colin 1979. La métrica del Poema de Mio Cid: Nuevas posibilidades. In: Nueva Revista de Filología Hispánica 28(1), 30-56.

https://doi.org/10.24201/nrfh.v28i1.1729

Tarlinskaja, Marina 1987. Shakespeare's Verse: Iambic Pentameter and the Poet's Idiosyncracies. New York: Peter Lang.

Tarlinskaja, Marina 1992. Metrical typology: English, German, and Russian dolnik verse. In: Comparative Literature 44(1), 1-21. https://doi.org/10.2307/1771165

Tarlinskaja, Marina 1993. Strict Stress Meter in English Poetry Compared with German and Russian. Calgary: University of Calgary Press.

Tarlinskaja, Marina 1995. Beyond "loose iamb": the form and themes of the English “dolnik". In: Poetics Today 16(3), 493-522. https://doi.org/10.2307/1773176

Tarlinskaja, Marina 2002. Verse text: its meter and its oral rendition. In: Küper, Christoph (ed.), Meter, Rhythm and Performance. Metrum, Rhythmus, Performanz. Frankfurt am Main: Peter Lang, 39-55.

Toledo, Guillermo Andrés 2002. Acentos en español: un problema para la fonología métrica. In: Verba 29, 119-138.

Tsur, Reuven 1998. Poetic Rhythm: Structure and Performance. Berne: Peter Lang.

Valle-Inclán, Ramón María del 1995. Claves líricas. 4th ed. Madrid: Espasa Calpe.

Vega, Garcilaso de la 2001. Obra poética y textos en prosa. Barcelona: Crítica.

Wright, George T. 1988. Shakespeare's Metrical Art. Berkeley: University of California Press. 


\section{Addenda}

\section{Underlying metrical presuppositions; the maximum}

\section{1a. Metrical presuppositions}

Within the linguistically-inflected approach adopted in this article (inspired by Tarlinskaja 2002; cf. Jakobson 1966: 364-366), I assume a basic distinction between performance or delivery (Jakobson's delivery design and delivery instance), rhythm (verse instance) and metre (verse design).

The performance includes such disparate phenomena as silent reading and a reciter's oral rendition.

The rhythm is that of the authorial realization of verse, established by the analyst in view of phonological knowledge and, when necessary, of the work done by textual editors.

As regards the metre, I take it to comprise three elements (cf. Kiparsky 1977: 190): a metrical template made up of strong and weak positions; metrical filters selecting what counts as a syllable and what syllables count as salient, that is, by means of which the prosodic material is metrified; realization rules connecting the template and the metrified materials, thus governing the author's choice of linguistic elements and the audience's expectations. My analysis focuses on the rhythm of the authorial realization and on the metre, not on a kind of delivery or on any individual performance. I assume that the metrified materials include neither pauses nor vocalic lengthenings (in Spanish, these two phonetic staples of temporal and musical theories of verse performance play no phonological role). I reject any tinkering with the linguistic features of lines, including the stresses, so that they will conform to the metre, a move which would "violate the linguistic givens of [the] language" as described by phonologists independently of verse analysis (Halle, Keyser 1966: 188), and which would render "almost any arrangement" of linguistic traits "metrically acceptable" (Halle, Keyser 1971: 162). In Spanish, this would push metrical verse in the direction of song. The treatment of stress in Spanish song involves the erasure of all preexisting stresses and the addition of new ones as called for by the tune (cf. Rodríguez Vázquez 2010; Domínguez Caparrós 2014: 75-76 n. 52): at best, this amounts to rendering all Spanish verse purely syllabic; at worst, to doing away with any linguistic regulation. Respecting linguistic strictures is a guarantee of methodological rigour and of the reproducibility of the analysis. Moreover, I distinguish those realizations that are correct (metrical, in an evaluative sense) from those that are incorrect (unmetrical). Finally, I focus on constant features; calculations of variable tendencies are confined to these Addenda. Without denying the usefulness of statistical methods when 
it comes to appreciating important stylistic nuances in the realization, to analysing the local effects of deviations from a given statistical norm, and even to fully characterizing a metre, I assume that, on their own, statistics cannot tell us what the metre is and what constitutes a correct realization thereof.

\section{1b. The maximum}

According to Halle and Keyser's original definition, the maximum is "a syllable bearing linguistically determined stress that is greater than that of the two syllables adjacent to it in the same verse" (Halle, Keyser 1966: 197). Different versions of the maximum appear in other joint works by Halle and Keyser, where they suggest, for example, that it is "a stressed syllable [...] located between two unstressed syllables in the same syntactic constituent within a line of verse" (Halle, Keyser 1971: 156), and also in Fabb, Halle (2008) and in Piera (2008), where different metres are said to demand different kinds of maxima based on different kinds of prosodic features (not only stress, but also tone, for example). The idea has a precedent in the theories of the Russian formalists; Jakobson, for example, states that in Russian "a stressed syllable cannot fall on the upbeat [weak position] if the downbeat [strong position] is fulfilled by an unstressed syllable of the same word" (1966: 361). Though by another name, the idea of the maximum also appears in Kiparsky (1977), according to whom English metres generally ban from weak positions a stress flanked by nonstresses in lexical polysyllables, such that the middle syllable in the word importance can only realize a strong position (but there might be exceptions to this rule too; cf. Shakespeare's and Milton's placement of words like Tiresias and universal in Kiparsky 1977: 201-203; and like temptation and dividable in Tsur 1998: 360). Hayes offers his own version of the maximum, calling it peak: a syllable stronger than "at least one of its neighbors" (1983:376). The notion of the maximum is also implicit in Tarlinskaja's works; she asserts, much like Kiparsky, that in English verse an internal stress in polysyllables like continues cannot realize weak positions (Tarlinskaja 1993: 10).

\section{Spanish metrics and phonology}

\section{2a. Spanish metrics}

In Spanish metrical verse, there is a distinction between verso simple and verso compuesto, that is, between what Piera calls a "unified" line (1981: 149), and what Clarke calls a "divided" or "compound" line (1964: 51 n. 1, 169). The short unified line (verso de arte menor) is usually distinguished from the long unified 
line (called, somewhat confusingly when dealing with Mena's metre, verso de arte mayor) in terms of their lengths. Where the frontier falls between both types is a bone of contention (cf. Domínguez Caparrós 2014: 134). Arguably, however (cf. Domínguez Caparrós 2014: 49), the difference is that the short unified line consists of one single metrical part or colon, while its long counterpart consists of at least two cola of equal or similar length, without internal extrametricality (this means that a word can straddle two cola). Metrically, the divided line can be explained as a combination of two or more independent hemistichs, i.e. of different unified lines placed side by side, all of which can have some extrametrical material at the end (so a word cannot straddle two hemistichs). The phenomenon of the divided line is very frequent in Spanish, where its use has long been systematically regulated; its sporadic counterpart is the phenomenon known as epic caesura (cf. Domínguez Caparrós 2014: 94 n. 67; for English, cf. Attridge 1982: 245; Wright 1988: 165-169). The defining characteristic of the divided line is that neither the length nor the structure of one hemistich affect the length or the structure of the next. Thus, one hemistich may end in one or more extrametrical syllables, or display no extrametricality at all; in the latter case, if the next hemistich begins with a strong position, two strong positions can appear back-to-back within the line (this does not mean that in between there may be unrealized or void weak positions: pace some analysts of arte mayor, in Spanish verse this phenomenon does not occur).

\section{2b. Spanish syllables}

In Spanish, only vocalic phonemes can be heads of syllables; there are two high vowels (/i/, written $i$ and $y$, and /u/, written $u$ and $\ddot{u})$, two mid vowels (/e/, written $e$, and /o/, written $o$ ) and one low vowel (/a/, written $a$ ). If, as Quilis claims (1993: 182-183), Spanish semivowels (glides) are only allophonic variants $([\mathrm{j}],[\mathrm{w}])$ of vocalic phonemes $(/ \mathrm{i} /, / \mathrm{u} /)$, then we can treat them just like any other vowel (cf. RAE 2011: 342). In principle, then, utterances have as many syllables as vowels, but almost any sequence of contiguous vowels, with or without an intervening $h$ (which in present-day Spanish is silent), can function as one single syllable in speech, as long as it does not follow the order lower-higher-lower (in which case we pronounce between two and as many syllables as vocalic phonemes there are in the sequence). Similarly, in metrical verse almost any vocalic sequence, with or without an intervening $h$, amounts to one or as many (metrified) syllables as vowels there are in it; if the sequence follows the order lower-higher-lower we count between two and as many syllables as vowels we find. Thus, the 5-vowel sequence in odio a 
Eurípides $=I$ hate Euripides can be treated as any number of syllables between one and five (cf. Navarro Tomás 1967: 72, 150-151). Witness how one strong metrical position is realized by the ending - a stressed vowel plus an unstressed vowel (plus a consonant) - of venían = they came in this 10-position line by Garcilaso de la Vega: "de dos pastores que venían cantan\{do\}" (Vega 2001: 244). Obviously, when verse lines are said aloud, all the vowels can be uttered, and pronounced as belonging to the same prosodic syllable or not: "it is just that some of them do not count for metrical purposes" (Piera 2008: 97).

\section{2c. Spanish stress}

In Spanish, syntactic words are prosodically divided into tónicas and átonas, that is, tonic (always stressed) and atonic (usually unstressed). The list of tonic forms includes all content words: nouns, adjectives, verbs and adverbs (Quilis 1993: 390-395; RAE 2011: 370-376), and most interjections. Simple words have one stress alone; compounds can have one or two stresses. As regards simple words, I take it that all trisyllabic and longer words and locutions are tonic. Some function monosyllables and disyllables - including the preposition según $(d)=$ according to/as (Quilis 1993: 392; RAE 2011: 417) - are tonic too. As regards compounds, some behave like simple words in that only the final element is tonic; but each part of the adverbs in -mente and of many other compounds counts as a tonic word; thus, for example, the adverb felizmente = happily has two stresses (Piera 1981: 214; Quilis 1993: 391; RAE 2011: 392-397; Hualde 2009: 202-204; 2010: 12; 2014: 226, 231-233). All other words - always function words in proclitic positions, including the poetic interjection $o(h)$ and the conjunction $\operatorname{sino}(n)=b u t$ (which I take to be oxytonic) - are atonic. (Enclitics are integrated in the preceding content word - necessarily a verb, whose preexisting stress does not move - such that the noun dique $=$ dam and the verb plus enclitic dime $=$ tell $m e$ have the same prosodic structure.)

Secondary stresses in Spanish remain a controversial issue. Their placement is usually explained either as conditioning that of the primary stress, or as being conditioned by it (cf. Morales-Front 2014: 259). In the former interpretation, secondary stresses are considered to obey the lexical rules that determine the structure of words; in the latter interpretation, they are regarded as postlexical (added by the utterer); in both interpretations, the assignment of secondary stresses is governed by the belief that Spanish words cannot have more than two contiguous nonstresses, at least to the left of the primary stress (Navarro Tomás 1967: 195-196; Harris 1983: 85-86, 96-97; Roca 1986; D'Introno et al. 1995: 156-173, 411-436). Although their existence is not 
explicitly denied by any author, I interpret the absence of references to lexical secondary stresses, in works such as Quilis (1993), as an implicit rejection. In general, the phonologists that admit the existence of lexical secondary stresses tend to accept Navarro Tomás's view that one or more of them can be placed to the left of the primary stress of the same word (on the first syllable and/or on a syllable separated from that primary stress by an odd number of unstressed syllables), and/or to the right of the primary stress (on a syllable separated from that primary stress by an odd number of syllables). Though postlexical secondary stresses are rejected by some authors (e.g. Toledo 2002: 135), their existence is widely recognized. According to Roca (1986), one or more of them can be inserted to the left of the primary stress of a word, but only on syllables separated from the primary stress by an odd number of syllables. According to Hualde (2009: 205-207; 2010; 2014: 252-253) and Hualde, Nadeu (2014: 244-247), one or more postlexical secondary stresses can optionally be placed to the left of the primary stress of a word, on the first syllable or on a syllable preceding the primary stress by an odd number of syllables, and/or on the final syllable that there may be to the right of that primary stress, provided that this syllable is an enclitic separated from the primary stress by at least one intervening syllable (for the latter phenomenon, cf. Navarro Tomás 1967: 196; RAE 2011: 412-413); however, postlexical secondary stresses placed to the left of a primary stress only appear in certain registers, where they serve, for example, to draw attention to the importance of the utterance (Hualde 2009: 206; 2010: 13-14; 2014: 252-253; Hualde, Nadeu 2014: 231), and postlexical secondary stresses to the right of the primary stress are even rarer. Postlexical strategies like stress deletion and (leftward) displacement have been suggested for a Romance language like Italian (cf. Nespor, Vogel 1989), but the latest linguistic research does not mention the possibility of these rhythmic procedures in Spanish.

\section{Arte mayor: Theories and problems}

\section{3a. Previous theories of arte mayor}

At the close of the 15th century, Nebrija described arte mayor as a divided line amounting to an "adónico doblado" = "double adonic": a repetition of the 5-syllable sequence dactyl-plus-"spondee" - i.e. trochee - totalling (due to the possible presence of one extrametrical syllable at the beginning of each sequence and the possible absence of a syllable at their end) between eight and eleven syllables up to the rightmost stress (2011: 71-73; cf. Balaguer 1995: 29-45). Navarro Tomás, from the camp of temporal metrics, speaks of two 
dactylic hemistichs of four syllables up to the rightmost stress (the nonstresses following this stress are optional, the dactylic ending is rare); either hemistich can optionally present 1- or 2-syllable initial extrametricality, thus reaching up to six syllables (normally five); in theory the total number of syllables of this divided line goes from eight to fourteen, but in practice it goes from nine to thirteen, as the optional nonstresses between the hemistichs are one or two, never zero or four; the rhythm is usually ternary within each hemistich, yet it can be binary (1974: 115-117). These are the only major accounts positing a falling metre.

In the late 16th century, Salinas described arte mayor as made up of amphibrachs (1983: 573-574). Somewhat later, Correas added that it contained from nine to eleven syllables, that some feet could be headless and that others could be truncated (Correas 1954: 472-475). More recently, other authors have followed suit (Bello 1884: 141-145; Piera 1981; Duffell 1999).

For Díaz Rengifo, also writing in the late 16th century, arte mayor was a divided form combining two rising hemistichs of five syllables, the second and fifth stressed, and with or without one extrametrical nonstress at the end of the hemistichs, which together add up to ten or eleven syllables (2012: 178-179). For Burger arte mayor is a divided form combining hemistichs of four and five syllables up to the rightmost stress; all other possible stresses depend on the versifier's personal style (1957: 34-35). Morel-Fatio analysed arte mayor as a divided form akin to the French decassyllable, with a break after the fifth syllable, "nécessairement accentué sur la cinquième syllable de chaque hémistiche" = "necessarily stressed on the fifth syllable of each hemistich", and whose syllabic irregularities must be ironed out either by the editor or in performance (1894: 211, 219-221). By suggesting the latter kind of correction, Morel-Fatio shows what some current metrical theories regard a misunderstanding of the relation between the metre, the rhythm of the authorial realization and the performance by a silent reader or by a reciter. The same charge can be levelled, as diagnosed by Duffell (1999: 11, 83-84), at the description provided by Lázaro Carreter (1972), which is still popular among textual editors (cf. John G. Cummins's remarks in Mena 1979: 44-46; Maxim P. A. Kerkhof's comments in Mena 1995: 105 n. 149). Contrary to those scholars who, as Piera puts it, believe that in Mena's days "reading habits did not impose the pattern stresses at the expense of the natural stress configuration" (1981: 144), Lázaro Carreter advocates what Clarke calls a "mechanical" chanting of the lines (1964: 56). He understands the arte mayor metre as consisting in divided lines, each hemistich with two strong positions realized by their respective stresses and separated by two nonstresses, and he believes in the "omnipotencia" = "omnipotence" of this metre (1972:350), to which the authorial realization and 
what he regards as the correct performance are subordinated: thus, stresses are added, deleted or displaced by the author so that they coincide with strong positions; and those stresses that do not undergo this authorial treatment must be wrenched, when necessary, by the performer.

Alternatively, arte mayor has been analysed not as a divided line but as a long unified line. Foulché-Delbosc posits a line consisting of two parts (equivalent to two cola). Each part has between four and seven syllabes = syllables, including two syllabes accentuées = accented syllables (strong positions), each realized by a stress separated by two syllabes non accentuées $=$ unaccented syllables (weak positions) corresponding to nonstresses; other nonstresses can be added at the beginning and at the end of each part. Together, both parts total between nine and twelve (usually eleven) syllables up to the last accented syllable. The structure of one part affects the other, to the effect that the last accented syllable of the initial part and the first of the final part must be separated by at least one unaccented syllable. Foulché-Delbosc contends that, when the first stress of a given part appears earlier than expected, this part has only one accented syllable, the last (1902: 94-103). In total he describes thirty-six line types in Laberinto and thirty-two further arte mayor possibilities (including lines with proparoxytonic endings). From other perspectives, the arte mayor line has been analysed as a unified line in which the initial colon contains between four and six syllables, and the final one contains between five and six (Roubaud 1971:380-381); as a line containing from seven to sixteen syllables (Saavedra Molina 1945: 65, 70), and as a metre whose weak positions are realized, at the beginning of the line, by zero to two syllables, and, elsewhere, by one to three - a form whose lines could therefore have, were it nor for the introduction of some ad hoc restrictions, between seven and fifteen syllables up to the rightmost stress (Piera 2008: 122).

\section{3b. Secondary stresses in arte mayor}

Spanish metrists tend to assume that secondary stresses coincide with (what they think to be) strong positions not realized by stressed heads (e.g. Balaguer 1995: 193 ff.; Domínguez Caparrós 2014: 75-76). In the absence of conclusive evidence, I assume that secondary stresses are inexistent or irrelevant for Laberinto. After all, irrespective of what many Spanish metrists and editors may think (cf. Cummins in Mena 1979: 177), all the linguistic descriptions of Spanish stress agree that, unless we adopt a chanting style, in a line like "reconoscerán, \# maguer que fero\{çe\}" (1. 2186 of Laberinto), the first word would never present a secondary stress on the second syllable, but only, if at 
all, on the first and/or third (the resulting scansions being $\mathrm{x} \times \mathrm{x} \times \mathrm{X}$ or $\mathrm{X} \times \mathrm{x}$ $\mathrm{x}$ X or X x X x X, or even $\mathrm{x}$ X X x X, but never x X x x X); in brief, this word does not conform to the ternary rhythm that many metrists demand from all lines of arte mayor. To this it must be added that in no variety of arte mayor has the last syllable of proparoxytones ever been said to realize the rightmost strong position of the line, so the alleged stresses at the end of rápido $=$ fast and of pensándolo = thinking it would not even behave as such.

\section{Mena's Laberinto}

\section{4a. Analysed lines according to line type and to colon and line ends}

There follows a list of the lines from Laberinto without consecutive or elided vowels, and without $h$ between vowels: there are 442 of them, i.e. $18.6 \%$ of the 2376 lines that make up Mena's work. There are two that I consider metrically incorrect: ${ }^{\star} 224$ (example (22)) and ${ }^{\star} 1563$ (example (21)). The ones that I consider metrically correct (440 lines, $18.5 \%$ ), and on which all subsequent statistics are based, are grouped according to line types, with those whose cola have been disambiguated (41 lines, $9.3 \%$ ) marked with a ? sign. Oxytonic ("masculine") endings are marked $m$ (43 lines, $9.8 \%$ ), paroxytonic ("feminine") endings are marked $f$, proparoxytonic ("dactylic") endings are marked $d$ (Laberinto consisting of unified lines, the paroxytonic and proparoxytonic endings of initial cola actually belong to the corresponding final cola; paroxytonic endings of final cola are extrametrical; proparoxytonic final-colon endings are systematically avoided):

- 5\#6 type (288 lines, $65.5 \%)$ :

- f\#f ("amphibrachic" type; 243 lines, 55.2 \%): 3, 9, 10, 21, 40, 55, 88, 114, 115, $131,155,156,163,168,174,179,201,208,211,232,259,260,284,288,311$, $365,371,374,390,391,401,404,424,428,439,443,445,465,467,474,481,491$, 498, 499, 509, 526, 541, 550, 556, 565, 588, 635, 651, 656, 657, 661, 664, 674, 682, $693,694,707,715,740,752,754,758,759,765,803,807,812,813,815,828,830$, $843,850,856,876,881,883,888,896,899,905,909,918,921,926,936,944,951$, $983,991,996,1040,1049,1067,1100,1107,1109,1111,1119,1120,1121,1126$, $1150,1153,1160,1161,1166,1167,1178,1181,1184,1186,1198,1204,1207$, $1218,1232,1235,1239,1253,1257,1262,1265,1283,1306,1307,1309,1318$, $1352,1360,1378,1407,1416,1440,1472,1477,1480,1484,1494,1496,1497$, $1500,1502,1504,1506,1509,1514,1520,1538,1554,1569,1573,1575,1576$, $1588,1600,1604,1609,1611,1629,1640,1642,1643,1645,1646,1647,1658$, 
$1665,1688,1703,1710,1731,1733,1738,1773,1789,1792,1796,1801,1802$, $1807,1809,1812,1816,1819,1831,1837,1853,1865,1878,1898,1902,1906$, 1910, 1911, 1914, 1916, 1939, 1960, 1976, 1980, 2003, 2014, 2017, 2019, 2037, $2041,2053,2111,2115,2138,2141,2142,2146,2153,2168,2173,2181,2200$, 2221, 2224, 2241, 2244, 2263, 2268, 2277, 2285, 2287, 2288, 2289, 2295, 2310, 2313, 2323, 2333, 2346, 2351, 2357.

- f\#m (24 lines, 5.5 \%): 319, 353, 409, 459, 504, 641, 681, 688, 705, 724, 728, 854, 861, 959, 1270, 1281, 1285, 1540, 1727, 1881, 1888, 1926, 2001, 2060.

- d\#f (14 lines, $3.2 \%): 569,730,963,965,973,1031,1073,1374,1605,1698,1849$, 2129, 2201, 2283.

- m\#f (4 lines, $0.9 \%): 561$ ?, 848, 1383?, 1448.

- d\#m (3 lines, $0.7 \%):$ 643, 957, 1342.

- 4 \#6 type (140 lines, $31.8 \%)$ :

- f\#f (116 lines, $26.4 \%):$ 15, 19?, 22, 54?, 56, 71, 82, 125?, 158?, 254, 454, 485?, $495,496,507,519,528$ ?, 572, 576, 580, 627?, 639, 649, 679, 704, 720, 733, 735, $738,789,832,836,842,845,882$ ?, 884, 887, 889, 911, 962, 971, 986, 1011, 1016, 1027 ?, 1043, 1063, 1069?, 1125, 1127, 1144, 1154, 1159?, 1185?, 1225?, 1259, 1297,1298 ?, 1312, 1328, 1358, 1364, 1369?, 1375, 1393, 1408, 1411, 1415, 1457, 1501,1517 ?, 1528, 1547, 1656, 1672, 1699, 1708, 1711, 1729?, 1739?, 1755?, 1776, 1790?, 1810, 1811?, 1818, 1843, 1869, 1873?, 1899, 1915, 1936, 1977, 1990, 1992?, 1995?, 1996?, 2026?, 2035, 2039, 2066, 2086?, 2107, 2119, 2127, 2216, 2235?, 2264, 2272, 2292?, 2294, 2321, 2343, 2344, 2353?, 2363?

- d\#f (13 lines, 3 \%): 506, 546, 702, 941, 1022, 1029, 1140, 1704, 1856, 1972, 2000 , 2081, 2094.

- f\#m (11 lines, 2.5 \%): 27?, 559, 855, 1455, 1591, 1844, 1848, 1931, 2005, 2057 , $2275 ?$

- $5 \# 5$ type (8 lines, $1.8 \%)$ :

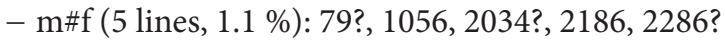

- m\#m (2 lines, $0.5 \%): 894$ ?, 1590.

- f\#f (1 line, $0.2 \%): 1037$.

- 4 \# 5 type (3 lines, $0.7 \%$ )

- m\#f (2 lines, $0.5 \%$ ): 167?, 307 ?

- f\#m (1 line, $0.2 \%): 1965$. 
- $6 \# 6$ type (1 line, $0.2 \%)$ :

- f\#m: 939.

All lines without contiguous vowels in which straddling proparoxytones end in 6 -syllable cola are correct. The only line without contiguous vowels in which a straddling proparoxytone does not end in a 6-syllable colon is $1 .{ }^{\star} 1563$ (example (21)), which has been considered incorrect.

\section{4b. General rhythmic tendencies in Mena's Laberinto}

The relation of stresses and nonstresses in each line type is the following (only syllables realizing metrical positions are taken into account, as all extrametrical syllables are nonstresses and nonmaxima; colon-final strong positions are underlined):

- 5\#6:

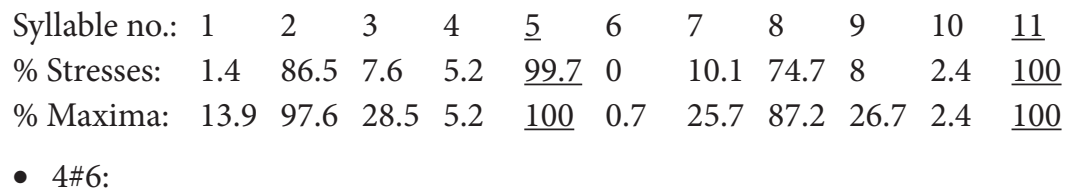




\section{4c. Ternary rhythmic tendencies in Mena's Laberinto}

In lines in which the final colon is realized by six syllables, ternary tendencies can hold throughout the line (i.e. both within and across cola):

- Lines with four noncontiguous maxima marking a ternary rhythm: (i) all maxima are stressed (112 lines, $25.5 \%$ ): 3, 9, 10, 21, 55, 114, 115, 131, 155, 174, 201, 254, 374, 391, 424, 428, 439, 467, 499, 541, 556, 576, 635, 639, 679, 694, 704, 715, 740, 754, 758, 765, 789, 845, 876, 905, 936, 939, 951, 962, 971, 973, 986, 1016, $1029,1049,1107,1109,1120,1144,1160,1166,1178,1181,1198,1262,1283$, $1285,1408,1477,1480,1497,1501,1502,1506,1573,1588,1600,1604,1640$, $1642,1647,1658,1665,1703,1708,1731,1802,1809,1818,1831,1843,1849$, 1856, 1881, 1902, 1906, 1914, 1936, 1939, 1960, 1977, 2014, 2017, 2019, 2053, 2066, 2081, 2127, 2129, 2141, 2173, 2200, 2221, 2244, 2263, 2264, 2277, 2288, 2289, 2310, 2313; (ii) not all maxima are stressed (15 lines, $3.4 \%$ ): 507, 519, 569, 702, 883, 957, 1411, 1457, 1554, 1591, 1699, 2000, 2216, 2283, 2285.

- Lines with more than four maxima but only four noncontiguous stresses marking a ternary rhythm (72 lines, $16.4 \%$ ): 71, 82, 88, 156, 168, 211, 259, 260, 409, 445, $454,496,546,561,565,688,724,730,733,738,752,812,828,830,848,854,855$, $888,926,944,959,996,1011,1073,1111,1161,1167,1184,1186,1207,1232$, $1257,1259,1306,1307,1309,1342,1360,1383,1440,1455,1484,1528,1540$, $1569,1646,1672,1727,1733,1801,1816,1848,1916,2039,2060,2094,2153$, 2181, 2268, 2272, 2287, 2351.

- Lines with four noncontiguous maxima not marking a ternary rhythm: (i) all maxima are stressed ( 8 lines, $1.8 \%$ ): 284, 651, 803, 1185, 1235, 1472, 2115, 2119; (ii) not all maxima are stressed (7 lines, 1.6 \%): 856, 1496, 1688, 1796, 1926, $2168,2275$.

- Lines with more than four maxima but only four noncontiguous stresses not marking a ternary rhythm (20 lines, $4.5 \%$ ): 465, 474, 498, 526, 707, 815, 896, 1407, 1520, 1547, 1575, 1609, 1853, 1992, 2019, 2026, 2037, 2111, 2292, 2346.

In lines in which the final colon is realized by five syllables, ternary tendencies hold either within cola or across them:

- Lines with four noncontiguous maxima marking a ternary rhythm in which not all maxima are stressed (1 line, $0.2 \%$ ): 1965 (ternary tendencies within cola).

- Lines with more than four maxima but only four noncontiguous stresses marking a ternary rhythm (1 line, $0.2 \%$ ): 1590 (ternary tendencies within cola). 
- Lines with four noncontiguous maxima not marking a ternary rhythm in which not all maxima are stressed (1 line, $0.2 \%): 2286$.

- Lines with more than four maxima but only four noncontiguous stresses not marking a ternary rhythm ( 1 line, $0.2 \%$ ): 894 (ternary tendencies across cola).

\section{4d. Realization of strong positions by nonmaxima placed next to maxima} Lines without vowels in which a nonmaximum realizing a strong position is next to a maximum, at least one of which belongs to a polysyllable (the provisional acceptance of headlessness in 4-syllable initial cola means that the displacement of the maximum always occurs in the final colon):

- in which the nonmaximum and the maximum do not belong to the same word: (i) within one foot, with leftward displacement of the maximum (14 lines, $3.2 \%$ ): 528, 705, 883, 909, 1185, 1472, 1688, 1796, 1807, 1865, 1926, 2168, 2275, 2346; (ii) across feet, with rightward displacement of the maximum (6 lines, $1.4 \%$, none of them with 4-syllable initial cola): 815, 1031, 1575, 1995, 1996, 2111.

- in which both the nonmaximum and the maximum belong to the same word, which therefore thwarts metrical expectations on more than one occasion: (i) within one foot, with leftward displacement of the maximum (20 lines, $4.5 \%$ ): $27,54,232,284,353,651,803,832,889,896,911,1239,1407,1415,1496,1547$, $1873,2037,2115,2295$; (ii) across feet, with rightward displacement of the maximum (9 lines, 2 \%): 319, 1609, 1611, 1755, 1837, 1972, 2026, 2119, 2292. 